Supporting Information

\title{
PyrPeg, a blood-brain barrier-penetrating two-photon imaging probe, selectively detects neuritic plaques, not tau aggregates
}

Ji-Woo Choi ${ }^{\dagger}, \diamond$ Yeon Ha Ju, ${ }^{\ddagger}, \S, \diamond$ Yunsook Choi, ${ }^{\prime, \perp}$ Seung Jae Hyeon, ${ }^{\#}$ Changdev G. Gadhe, ${ }^{\nabla}$

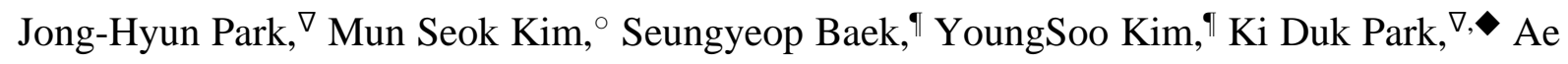

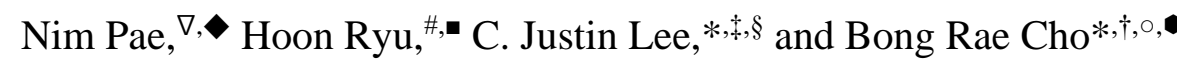

${ }^{\dagger}$ KU-KIST Graduate School of Converging Science and Technology, Korea University, 145 Anam-ro, Seongbuk-gu, Seoul, 02841, Republic of Korea

Center for Cognition and Sociality, Institute for Basic Science (IBS), 55 Expo-ro, Yuseong-gu, Daejeon, 34126, Republic of Korea

${ }^{\S}$ IBS School, University of Science and Technology (UST), 217 Gajeong-ro, Yuseong-gu, Daejeon, 34113, Republic of Korea

"Center for Functional Connectomics, Korea Institute of Science and Technology (KIST), 5 Hwarangro 14-gil, Seongbuk-gu, Seoul, 02792, Republic of Korea

${ }^{\perp}$ Department of Cellular and Molecular Physiology, Yale University School of Medicine, New Haven, CT 06511, USA

" Centers for Neuromedicine and Neuroscience, Brain Science Institute, KIST, 5 Hwarangro 14-gil, Seongbuk-gu, Seoul, 02792, Republic of Korea

$\nabla$ Convergence Research Center for Diagnosis, Treatment and Care System of Dementia, KIST, 5 Hwarangro 14-gil, Seongbuk-gu, Seoul, 02792, Republic of Korea

${ }^{\circ}$ Department of Chemistry, Daejin University, 1007 Hoguk-ro, Pocheon-si, Gyeonggi-do, 11159, Republic of Korea

II Integrated Science and Engineering Division, Department of Pharmacy and Department of Biotechnology, and Yonsei Institute of Pharmaceutical Sciences, Yonsei University, 85 Songdogwahakro, Yeonsu-gu, Incheon, 21983, Republic of Korea

- KHU-KIST Department of Converging Science and Technology, Kyung Hee University, Seoul, 02447, Republic of Korea

- Boston University Alzheimer's Disease Center (BU ADC) and Departments of Neurology, Boston University School of Medicine, Boston, MA 02118, USA

- Department of Chemistry, Korea University, 145 Anam-ro, Seongbuk-gu, Seoul, 02841, Republic of Korea

$\diamond_{\text {These authors contributed equally to this article }}$ 
Figure S1. (a) One-photon absorption spectra of PyrPeg at various concentrations and (b) a plot of the absorbance intensity against PyrPeg concentration in PBS.

Figure S2. Normalized absorption (a) and emission (b) spectra of PyrPeg in various solvents

Figure S3. (a,b) OPM images of $\alpha$-syn-treated and tau 441-treated astrocytes colabeled either with $\alpha$-syn, PyrPeg, and GFAP (a) or with tau 441, PyrPeg, and GFAP (b) and merged images (the images of GFAP fluorescence are omitted for simplicity). The cells were pretreated with $\alpha$-syn (a) and tau 441 (b) for 1 day. Representative images from replicate experiments $(n=5)$ are displayed.

Figure S4. (a,b) TPM images of PyrPeg-labeled SH-SY5Y cells untreated (a) and treated (b) with A $\beta$ fibrils. (c) Relative TPEF intensity in regions A-C and D-F in Figures S2a and S2b, respectively. TPM images were captured at 450-650 nm upon excitation at $750 \mathrm{~nm}$. Representative images from replicate experiments $(n=5)$ are presented. Scale bar: $30 \mu \mathrm{m}$

Figure S5. (a,b) An SPR sensorgram (a) and a binding curve (b) for the binding of PyrPeg to $A \beta_{42}$ monomers. (c,d) An SPR sensorgram (c) and a binding curve (d) for the binding of PyrPeg to $A \beta_{42}$ fibrils at low PyrPeg concentration. Blue dots are the experimental data, and black curves are the fitted curves obtained using the BIAcore evaluation software.

Figure S6. Binding of PyrPeg to the $\mathrm{A} \beta$ multimer. 2D interaction patterns of PyrPeg inside the $\mathrm{A} \beta 42$ multimers

Figure S7. (a,b) Schematic diagram of the dose-dependent (a) and time-dependent (b) labeling experiments on tail-injected mice. (c) OPM images of an APP/PS1 mouse brain slice injected with DMSO (vehicle). (d,f) OPM images of APP/PS1 mouse brain slices 1 day after injection with $1-20 \mathrm{mg} / \mathrm{kg}$ PyrPeg (d) and $3 \mathrm{~h}$ to 2 weeks after injection with $1 \mathrm{mg} / \mathrm{kg}$ PyrPeg (f). Inset scale bar: $5 \mu \mathrm{m}$. (e,g) Total area, average plaque size, plaque area (\%), and the number of plaques in the APP/PS1 mouse brain slices 1 day after injection with $1-20 \mathrm{mg} / \mathrm{kg}$ PyrPeg (d) and $3 \mathrm{~h}$ to 2 weeks after injection with $1 \mathrm{mg} / \mathrm{kg}$ PyrPeg (f). $* P<0.05$, $* * P<0.01$, *** $P<0.001$, $* * * * P<$ 0.0001 , one-way ANOVA with Tukey's multiple-comparison test. Representative images from replicate experiments $(\mathrm{n}=3)$ are provided.

Figure S8. $(a, b)$ Viability of PyrPeg-treated astrocytes according to the MTT assay (a) and viability of PyrPeg-treated SH-SY5Y cells according to the CCK-8 assay (b). The cells were incubated with PyrPeg $(1-10 \mu \mathrm{M})$ for $24 \mathrm{~h}$. (c) Survival rates of C57BL/6J mice 1-7 days after intravenous injection with PyrPeg $(10-100 \mathrm{mg} / \mathrm{kg})$ into the tail. 
Figure S9. (a-d) TPM and (e-h) bright-field images of APP/PS1 mouse brain slices labeled with $0.1(\mathrm{a}, \mathrm{e}), 0.25(\mathrm{~b}, \mathrm{f}), 0.5(\mathrm{c}, \mathrm{g})$, or $1.0 \mu \mathrm{M}(\mathrm{d}, \mathrm{h})$ PyrPeg. TPM images were acquired at $450-650 \mathrm{~nm}$ upon excitation at $750 \mathrm{~nm}$. (g) The plot of TPEF intensity vs. PyrPeg concentration in the staining medium, as retrieved from the white circled

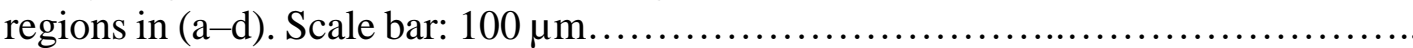

Figure S10. (a-d) TPM (a,b,d) and OPM (c) images of SH-SY5Y cells labeled with PyrPeg, and (b) APP/PS1 mouse brain slices labeled with PyrPeg (b) or Th-S (c). An APP/PS1 mouse brain slice 1 day after i.p. injection with MeO-X04 (2 mg/kg) (d). $(\mathrm{e}-\mathrm{h})$ Relative TPEF $(\mathrm{a}, \mathrm{b}, \mathrm{d})$ and one-photon fluorescence intensities in regions A-C as a function of time. The digitized intensity was recorded with $1.63 \mathrm{~s}$ intervals for 1 $\mathrm{h}$ in $x y t$ mode. The TPEF and one-photon fluorescence intensities were determined at $450-650 \mathrm{~nm}$ upon excitation at 750 and $458 \mathrm{~nm}$ with femtosecond pulses and continuous waves, respectively. Scale bar: $30 \mu \mathrm{m}$.

Figure S11. OPM images of WT mouse brain tissue labeled with Th-S (a) or PyrPeg (b). The fluorescence intensities were collected at 450-650 $\mathrm{nm}$ upon excitation at 458 $\mathrm{nm}$. Scale bar: $30 \mu \mathrm{m}$.

Figure S12. OPM images of the normal and AD patient's brain sections labeled with A $\beta$ (blue), AT8 (red), and PyrPeg (green) and a merged image....

Figure S13. (a) OPM images of an APP/PS1 mouse brain section colabeled with A $\beta$ (blue), AT8 (red), and PyrPeg (green) and a merged image. (b) Line measurement analysis along the white line in the merged image of (a). Representative images from replicate experiments $(\mathrm{n}=3)$ are displayed...

Figure S14. (a) OPM images of APP/PS1 mouse brain slices stained with an anti-A $\beta$ antibody (blue), PyrPeg (green), anti-Iba1 antibody (red), and anti-GFAP antibody (magenta). Representative images from replicate experiments $(n=3)$ are shown. (b) A plot of PyrPeg-positive vs. A $\beta$-positive areas using 103 data points from five OPM images. The green dots are the experimental data, and the straight line is the linear regression line that can be represented by the empirical equation shown in the figure...

Figure S15. The gel analysis of the $A \beta_{42}$ mixture produced by incubating $A \beta_{42}$ monomer with Th-S or PyrPeg for 0 and 4 days, followed by photo-induced crosslinking of unmodified proteins. The image on the left was obtained by exciting the gel at $473 \mathrm{~nm}$ using a green filter, while that on the right was obtained by silver staining. The images show that $A \beta_{42}$ fibrils are the predominant product after 4 days

Figure S16. ${ }^{1} \mathrm{H}$ NMR $\left(500 \mathrm{MHz}, \mathrm{CDCl}_{3}\right)$ of compound 3

Figure S17. ${ }^{13} \mathrm{C} \mathrm{NMR}\left(100 \mathrm{MHz}, \mathrm{CDCl}_{3}\right)$ of compound 3.

Figure S18. ${ }^{1} \mathrm{H}$ NMR $\left(500 \mathrm{MHz}, \mathrm{CDCl}_{3}\right)$ of compound 4

Figure S19. ${ }^{13} \mathrm{C} \mathrm{NMR}\left(100 \mathrm{MHz}, \mathrm{CDCl}_{3}\right)$ of compound 4.................... S16

Figure S20. ${ }^{1} \mathrm{H}$ NMR $\left(500 \mathrm{MHz}, \mathrm{CDCl}_{3}\right)$ of compound 5. 
Figure S21. ${ }^{13} \mathrm{C} \mathrm{NMR}\left(100 \mathrm{MHz}, \mathrm{CDCl}_{3}\right)$ of compound 5

Figure S22. ${ }^{1} \mathrm{H} \mathrm{NMR}\left(500 \mathrm{MHz}, \mathrm{CDCl}_{3}\right)$ of compound 6.

Figure S23. ${ }^{13} \mathrm{C} \mathrm{NMR}\left(100 \mathrm{MHz}, \mathrm{CDCl}_{3}\right)$ of compound 6. S18

Figure S24. ${ }^{1} \mathrm{H} \mathrm{NMR}\left(500 \mathrm{MHz}, \mathrm{CDCl}_{3}\right)$ of PyrPeg. S19

Figure S25. ${ }^{13} \mathrm{C} \mathrm{NMR}\left(100 \mathrm{MHz}, \mathrm{CDCl}_{3}\right)$ of PyrPeg. S19

Figure S26. HRMS of PyrPeg. S20

Table S1. Photophysical properties of PyrPeg, QAD1, SAD1, and A $\beta$ probe 5. S21

Table S2. Human brain tissue samples of healthy subjects and AD patients $\mathrm{S} 22$

Table S3. The PAMPA-BBB assay. $\mathrm{S} 22$

References. S22

\section{Synthesis of PyrPeg}

Compounds $\mathbf{1}$ and $\mathbf{2}$ were prepared by published methods. ${ }^{1}$

\section{Compound 3}

A solution of compound $2(3.0 \mathrm{~g}, 22 \mathrm{mmol})$ in $10 \mathrm{~mL}$ of $\mathrm{CH}_{2} \mathrm{Cl}_{2}$ was added dropwise to a stirred solution of 2-nitrobenzenesulfonyl chloride (5.3 g, $24 \mathrm{mmol})$ and pyridine (3.5 mL, $44 \mathrm{mmol})$ in $\mathrm{CH}_{2} \mathrm{Cl}_{2}(30 \mathrm{~mL})$. The mixture was stirred at room temperature (RT) for $3 \mathrm{~h}$. Then, the solvent was evaporated, and the residue was dissolved in ethyl acetate. The organic layer was washed with a saturated aqueous $\mathrm{NaHCO}_{3}$ solution, separated, and purified using hexane/EtOAc (3/1) as the eluent, resulting in a brown solid. Yield: $5.4 \mathrm{~g}(77 \%) ;{ }^{1} \mathrm{H} \mathrm{NMR}\left(500 \mathrm{MHz}, \mathrm{CDCl}_{3}\right): \delta$ $7.66(1 \mathrm{H}, \mathrm{ddd}, J=8.5,8.1,1.5 \mathrm{~Hz}), 7.59(1 \mathrm{H}, \mathrm{dd}, J=8.1,1.5 \mathrm{~Hz}), 7.57(1 \mathrm{H}, \mathrm{dd}, J=8.1,1.5$ $\mathrm{Hz}), \delta 7.51(1 \mathrm{H}$, ddd, $J=8.5,8.1,1.5 \mathrm{~Hz}), 7.22(1 \mathrm{H}, \mathrm{t}, J=8.1 \mathrm{~Hz}), 6.84(1 \mathrm{H}, \mathrm{ddd}, J=8.3$, 2.4, $0.9 \mathrm{~Hz}), 6.82(1 \mathrm{H}, \mathrm{t}, J=2.2 \mathrm{~Hz}), 6.78(1 \mathrm{H}, \mathrm{ddd}, J=8.1,2.0,1.0 \mathrm{~Hz}), 3.76(3 \mathrm{H}, \mathrm{s}), 3.38$ $(3 \mathrm{H}, \mathrm{s}) .{ }^{13} \mathrm{C} \mathrm{NMR}\left(100 \mathrm{MHz}, \mathrm{CDCl}_{3}\right): \delta 160.3,148.5,141.7,134.3,131.7,131.5,130.9,130.2$, 124.0, 119.4, 113.9, 113.6, 55.7, 39.5 ppm. 


\section{Compound 4}

$\mathrm{BBr}_{3}\left(1.0 \mathrm{M}\right.$ in $\mathrm{CH}_{2} \mathrm{Cl}_{2}, 12.6 \mathrm{~mL}, 12.6 \mathrm{mmol}$ ) was added dropwise to a solution of compound $3(3.4 \mathrm{~g}, 11 \mathrm{mmol})$ in $\mathrm{CH}_{2} \mathrm{Cl}_{2}(100 \mathrm{ml})$ at $-78^{\circ} \mathrm{C}$ for $20 \mathrm{~min}$. Next, the mixture was stirred for $2 \mathrm{~h}$ at $-78{ }^{\circ} \mathrm{C}$, gradually warmed to RT, and stirred for $16 \mathrm{~h}$. The mixture was cooled to $0{ }^{\circ} \mathrm{C}$, quenched by the slow addition of ice-cold water, and neutralized with $\mathrm{NaHCO}_{3}$. The organic layer was separated, and the aqueous phase was extracted with $\mathrm{CH}_{2} \mathrm{Cl}_{2}$. The residue was dried over $\mathrm{MgSO}_{4}$ and the solvent was evaporated to obtain the product. The residue was purified by silica gel column chromatography with hexane-EtOAc $(1: 1)$ as the eluent, resulting in a brown solid. Yield: $3.1 \mathrm{~g}(95 \%)$; $1 \mathrm{H} \mathrm{NMR}\left(500 \mathrm{MHz}, \mathrm{CDCl}_{3}\right)$ : $\delta 7.66(1 \mathrm{H}$, ddd, $J=7.9,7.3,1.4 \mathrm{~Hz}$ ), $7.58(2 \mathrm{H}, \mathrm{ddd}, J=7.9,4.9,1.4 \mathrm{~Hz}), 7.52(1 \mathrm{H}, \mathrm{ddd}, J=8.0,7.3,1.3 \mathrm{~Hz}), 7.16(1 \mathrm{H}, \mathrm{t}, J=8.3$ $\mathrm{Hz}), 6.80-6.77(2 \mathrm{H}, \mathrm{m}), 6.73(1 \mathrm{H}, \mathrm{ddd}, J=7.7,1.8,1.0 \mathrm{~Hz}), 3.36(3 \mathrm{H}, \mathrm{s}) .{ }^{13} \mathrm{C}$ NMR (100 $\left.\mathrm{MHz}, \mathrm{CDCl}_{3}\right): \delta 156.7,148.5,141.6,134.1,131.9,131.4,131.1,130.4,124.0,119.2,115.6$, 115.0, $39.6 \mathrm{ppm}$.

\section{Compound 5}

Dry paraformaldehyde $(5.8 \mathrm{~g}, 190 \mathrm{mmol})$ was added to a mixture of compound 4 (3.0 g, 9.7 $\mathrm{mmol})$, anhydrous $\mathrm{MgCl}_{2}(3.7 \mathrm{~g}, 39 \mathrm{mmol})$, and dry $\mathrm{Et}_{3} \mathrm{~N}(5.1 \mathrm{~mL}, 37 \mathrm{mmol})$ in dry $\mathrm{MeCN}$ at RT, and the mixture was refluxed for $8 \mathrm{~h}$ under Ar. Upon complete consumption of the phenol, as determined by thin-layer chromatography, the mixture was cooled and the reaction was quenched by adding water. The mixture was acidified with $\mathrm{HCl}(1 \mathrm{~N})$ and extracted with ethyl acetate. The extracts were dried over $\mathrm{MgSO}_{4}$, and the solvent was evaporated. The crude product was purified by silica gel column chromatography using hexane-EtOAc $(1: 1)$ as the eluent to obtain compound 5. Yield: $1.7 \mathrm{~g}(52 \%) ;{ }^{1} \mathrm{H}$ NMR $\left(500 \mathrm{MHz}, \mathrm{CDCl}_{3}\right): \delta 11.08(1 \mathrm{H}$, s), $9.81(1 \mathrm{H}, \mathrm{s}), 7.72-7.69(2 \mathrm{H}, \mathrm{m}), 7.62-7.59(2 \mathrm{H}, \mathrm{m}), 7.52(1 \mathrm{H}, \mathrm{d}, J=8.5 \mathrm{~Hz}), 6.98(1 \mathrm{H}$, $\mathrm{dd}, J=8.5,2.1 \mathrm{~Hz}), 6.81(1 \mathrm{H}, \mathrm{d}, J=2.1 \mathrm{~Hz}), 3.37(3 \mathrm{H}, \mathrm{s}) .{ }^{13} \mathrm{C} \mathrm{NMR}\left(100 \mathrm{MHz}, \mathrm{CDCl}_{3}\right): \delta$ $196.1,162.3,148.4,148.2$, 134.8, 134.8, 132.0, 131.5, 130.6, 124.5, 119.2, 117.2, 113.6, 38.5 ppm. 


\section{Compound 6}

A mixture of compound 5 (1.5 g, $4.5 \mathrm{mmol}), 1$ (1.8 g, $4.5 \mathrm{mmol})$, and $\mathrm{K}_{2} \mathrm{CO}_{3}(1.3 \mathrm{~g}, 9.0 \mathrm{mmol})$ in dimethylformamide (45 mL) was stirred for $12 \mathrm{~h}$ at $100{ }^{\circ} \mathrm{C}$ under Ar. The mixture was filtered, the filtrate was evaporated, and the crude product was purified by column chromatography (silica gel), with $\mathrm{CH}_{2} \mathrm{Cl}_{2}-$ EtOAc (1:1) as the eluent to obtain an orange solid. Yield: $1.2 \mathrm{~g} \mathrm{(42 \% );}{ }^{1} \mathrm{H}$ NMR (500 MHz, $\left.\mathrm{CDCl}_{3}\right): \delta 9.02(2 \mathrm{H}, \mathrm{s}), 7.68-7.64(1 \mathrm{H}, \mathrm{m}), 7.61-7.59$ (1 H, m), 7.57-7.55 (2 H, m), 7.50-7.47 (3 H, m), $7.43(2 \mathrm{H}, \mathrm{dd}, J=6.6,1.0 \mathrm{~Hz}), 7.15(1 \mathrm{H}$, $\mathrm{dd}, J=8.4,1.8 \mathrm{~Hz}), 7.08(1 \mathrm{H}, \mathrm{d}, J=2.0 \mathrm{~Hz}), 6.91(1 \mathrm{H}, \mathrm{dd}, J=8.8,2.2 \mathrm{~Hz}), 4.19-4.17(2 \mathrm{H}$, m), 3.90-3.88 (2 H, m), 3.74-3.72 (2 H, m), 3.60-3.58 (2 H, m), 3.45 (3 H, s), 3.39 (3 H, s). ${ }^{13} \mathrm{C}$ NMR (100 MHz, $\left.\mathrm{CDCl}_{3}\right): \delta 158.8,157.0,155.3,154.6,151.9,148.5,143.8,142.2,140.9$, $140.6,138.3,134.2,131.9,131.5,131.1,128.5,124.1,123.5,122.3,122.2,122.1,113.9,111.5$, 107.7, 106.4, 96.9, 72.2, 71.0, 69.9, 68.1, 59.3, 40.1 ppm.

\section{PyrPeg}

Thiophenol $(0.11 \mathrm{~mL}, 1.1 \mathrm{mmol})$ was added to a mixture of compound $6(0.58 \mathrm{~g}, 0.90 \mathrm{mmol})$ and $\mathrm{K}_{2} \mathrm{CO}_{3}(0.25 \mathrm{~g}, 1.8 \mathrm{mmol})$ in dimethylformamide $(10 \mathrm{~mL})$ and the mixture was stirred at RT for $16 \mathrm{~h}$. The mixture was diluted with $\mathrm{CH}_{2} \mathrm{Cl}_{2}(40 \mathrm{~mL})$ and the combined organic layer was extracted with water. The organic layer was washed with brine, separated, dried over $\mathrm{MgSO}_{4}$, and evaporated. The crude product was purified by column chromatography with $\mathrm{CH}_{2} \mathrm{Cl}_{2}$-EtOAc (1:1) as the eluent to obtain an orange solid. Yield: $0.22 \mathrm{~g}(53 \%) .{ }^{1} \mathrm{H}$ NMR $\left(500 \mathrm{MHz}, \mathrm{CDCl}_{3}\right): \delta 8.96(2 \mathrm{H}, \mathrm{q}, J=1.6 \mathrm{~Hz}), 7.47(1 \mathrm{H}, \mathrm{d}, J=8.5 \mathrm{~Hz}), 7.36(1 \mathrm{H}, \mathrm{d}, J=8.5$ $\mathrm{Hz}), 7.36(1 \mathrm{H}, \mathrm{d}, J=0.8 \mathrm{~Hz}), 7.34(1 \mathrm{H}, \mathrm{d}, J=0.8 \mathrm{~Hz}), 7.09(1 \mathrm{H}, \mathrm{d}, J=1.9 \mathrm{~Hz}), 6.91(1 \mathrm{H}$, $\mathrm{dd}, J=8.8,2.2 \mathrm{~Hz}), 6.72(1 \mathrm{H}, \mathrm{d}, J=1.0 \mathrm{~Hz}), 6.57(1 \mathrm{H}, \mathrm{dd}, J=8.5,1.9 \mathrm{~Hz}), 4.19-4.17(2 \mathrm{H}$, m), 3.90-3.88 (2H, m), 3.75-3.73 (2 H, m), 3.60-3.59 (2 H, m), 3.40 (3 H, s), 2.88 (3 H, s). ${ }^{13} \mathrm{C}$ NMR $\left(100 \mathrm{MHz}, \mathrm{CDCl}_{3}\right): \delta 158.5,158.2,156.8,152.4,150.5,149.4,143.4,142.3,140.6$, $140.4,122.3,122.2$, 122.1, 119.3, 113.7, 112.3, 107.5, 106.5, 96.9, 93.3, 72.2 , 71.1, 70.0, 68.1, 59.4, $31.1 \mathrm{ppm}$. High-resolution mass spectrometry (HRMS) (electrospray ionization; ESI): $\mathrm{m} / \mathrm{z}$ calcd. for $\left[\mathrm{C}_{26} \mathrm{H}_{25} \mathrm{~N}_{3} \mathrm{O}_{5}+\mathrm{H}^{+}\right]$: 460.18670 ; found: 460.18679 . 
(a)

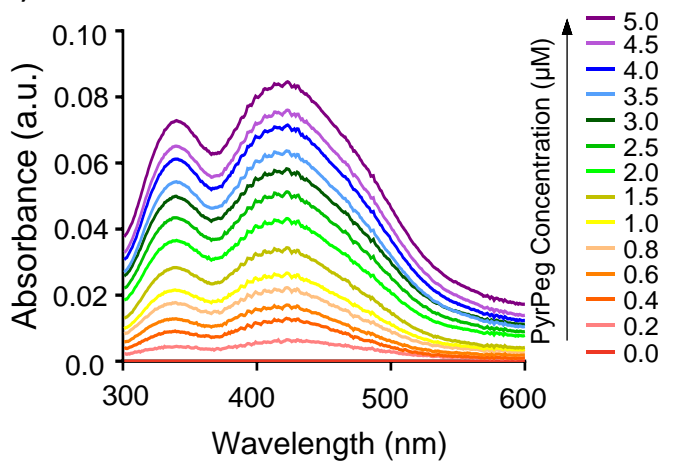

(b)

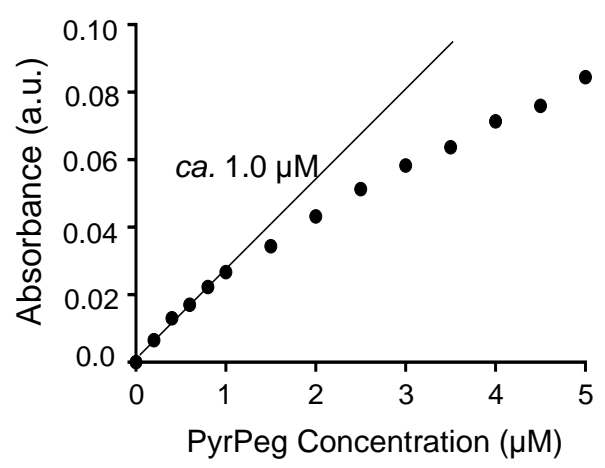

Figure S1. (a) One-photon absorption spectra of PyrPeg at various concentrations, and (b) a plot of the absorbance intensity against PyrPeg concentration in PBS.

(a)

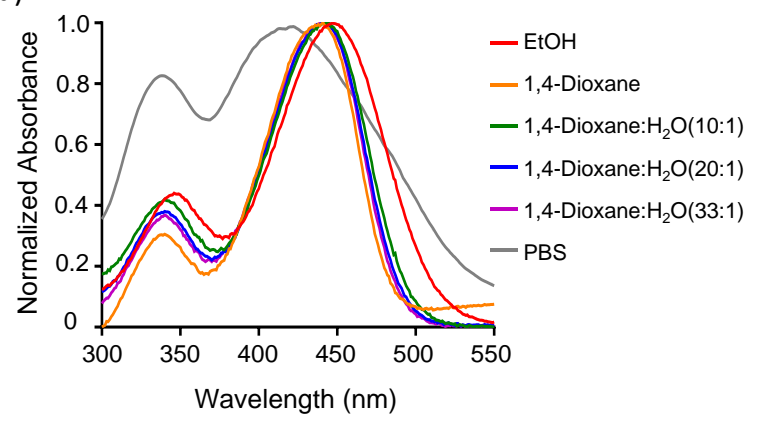

(b)

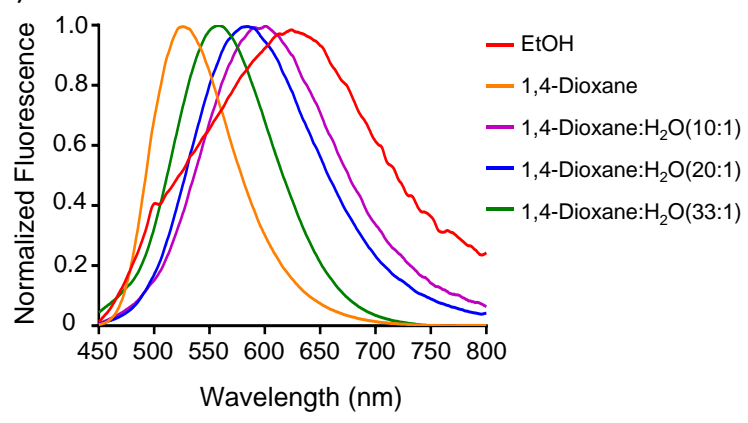

Figure S2. Normalized absorption (a) and emission (b) spectra of PyrPeg in various solvents. 


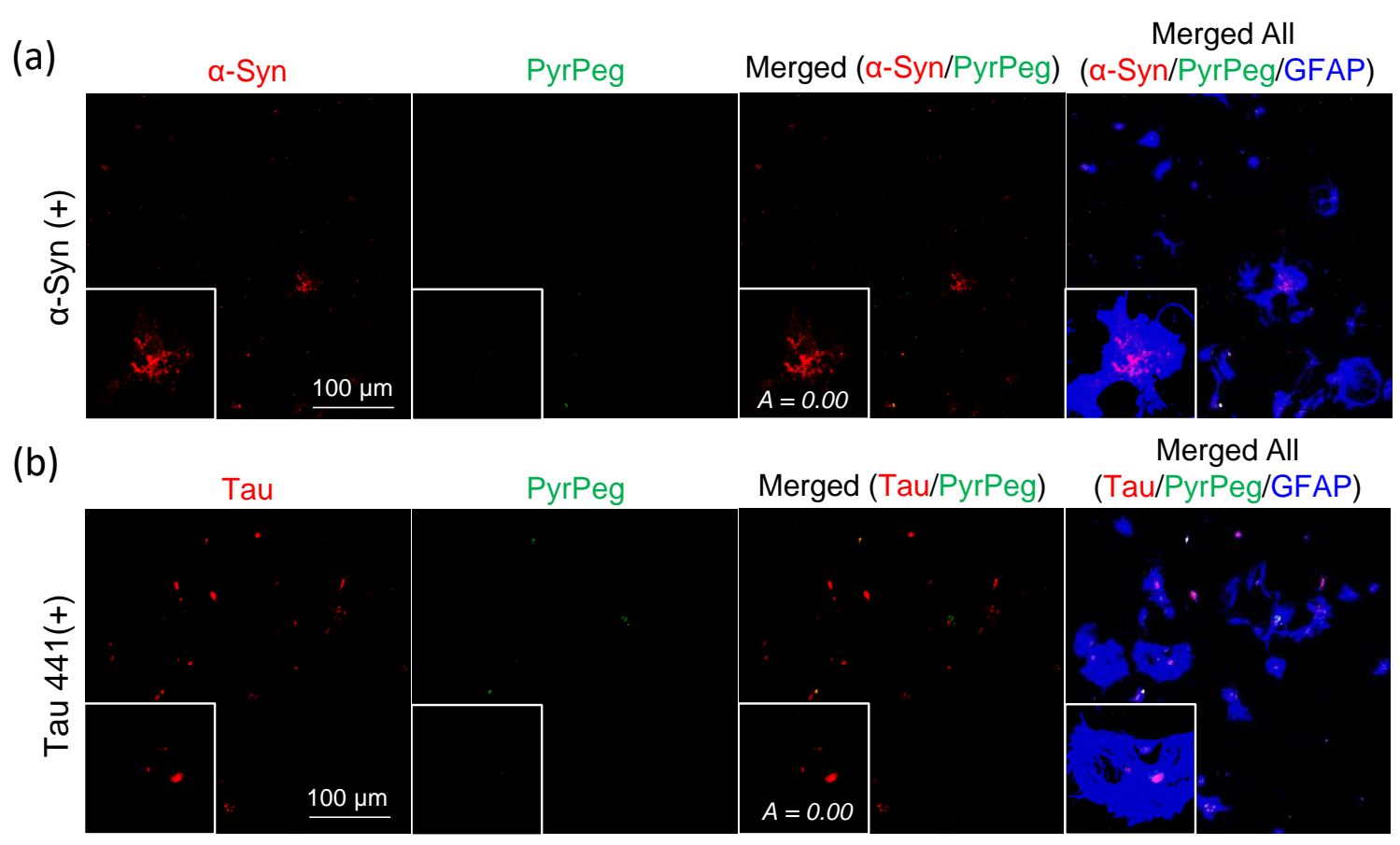

Figure S3. (a,b) OPM images of $\alpha$-syn-treated and tau 441-treated astrocytes colabeled either with $\alpha$-syn, PyrPeg, and GFAP (a) or with tau 441, PyrPeg, and GFAP (b) and merged images (the images of GFAP fluorescence are omitted for simplicity). The cells were pretreated with $\alpha$-syn (a) and tau 441 (b) for 1 day. Representative images from replicate experiments $(n=5)$ are displayed.
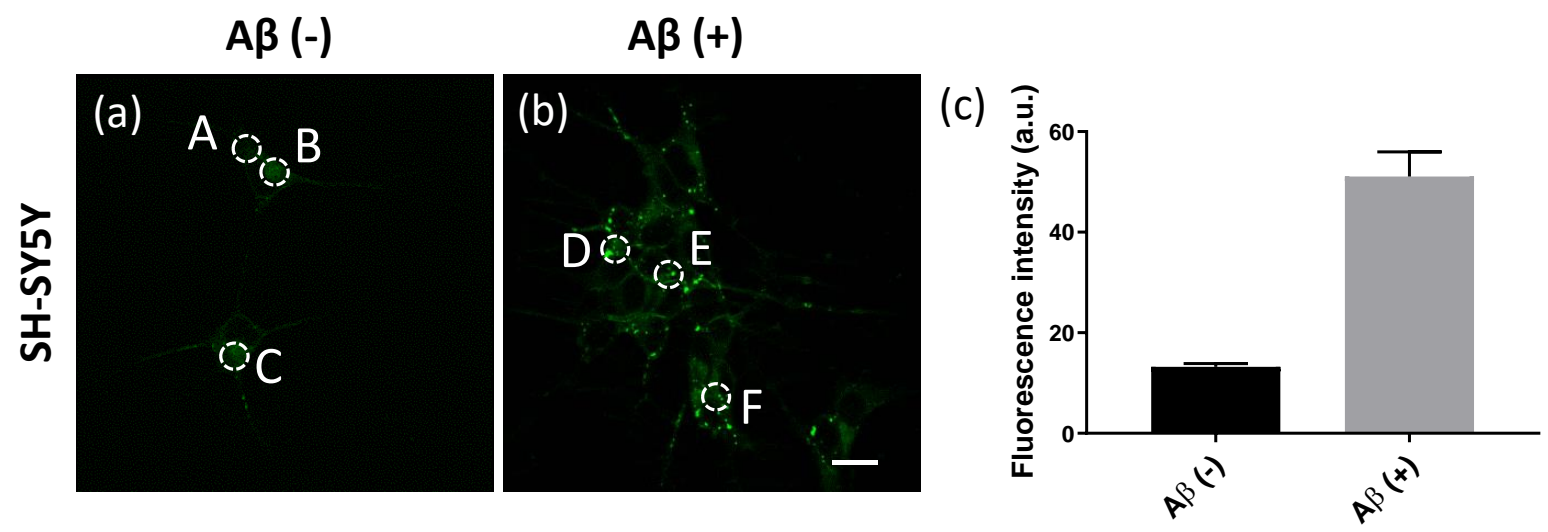

Figure S4. (a,b) TPM images of PyrPeg-labeled SH-SY5Y cells untreated (a) and treated (b) with $A \beta$ fibrils. (c) Relative TPEF intensity in regions A-C and D-F in Figures S2a and S2b, respectively. TPM images were captured at 450-650 nm upon excitation at $750 \mathrm{~nm}$. Representative images from replicate experiments $(n=5)$ are presented. Scale bar: $30 \mu \mathrm{m}$. 
(a)

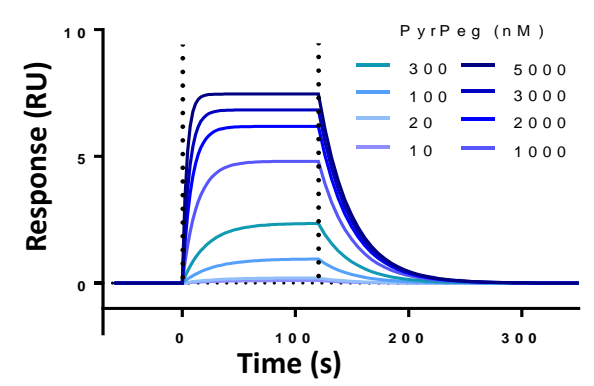

(c)

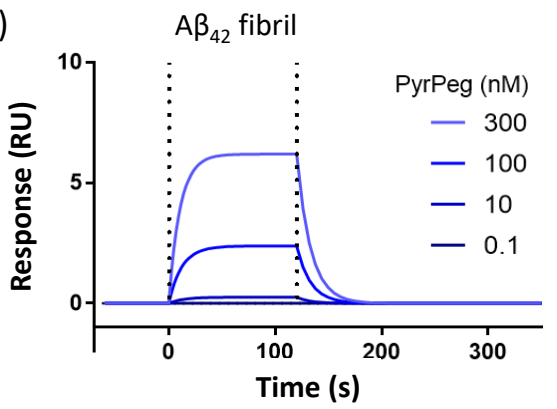

(b)

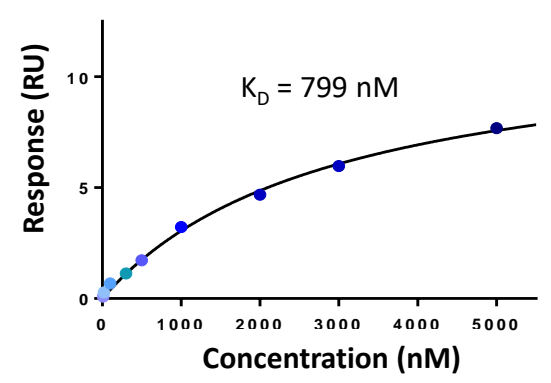

(d)

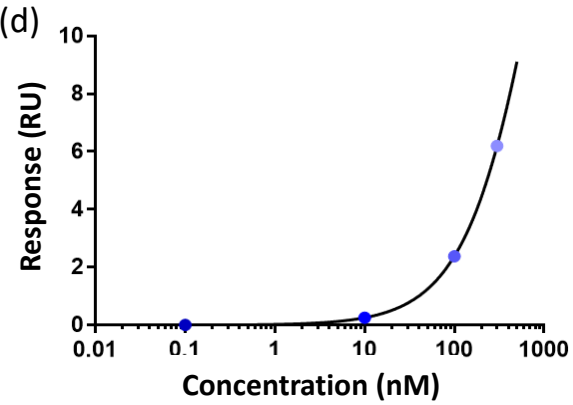

Figure S5. (a,b) An SPR sensorgram (a) and a binding curve (b) for the binding of PyrPeg to $A \beta_{42}$ monomers. (c,d) An SPR sensorgram (c) and a binding curve (d) for the binding of PyrPeg to $\mathrm{A} \beta_{42}$ fibrils at low PyrPeg concentration. Blue dots are the experimental data, and black curves are the fitted curves obtained using the BIAcore evaluation software.

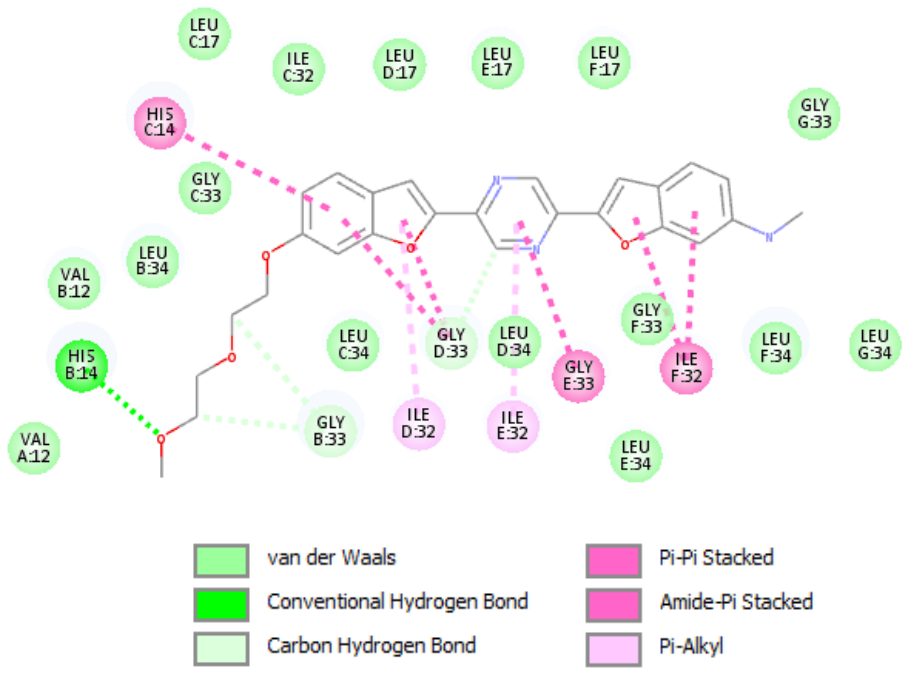

Figure S6. Binding of PyrPeg to the $A \beta$ multimer. 2D interaction patterns of PyrPeg inside the $\mathrm{A} \beta_{42}$ multimers. 
a

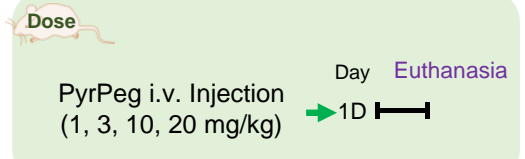

d
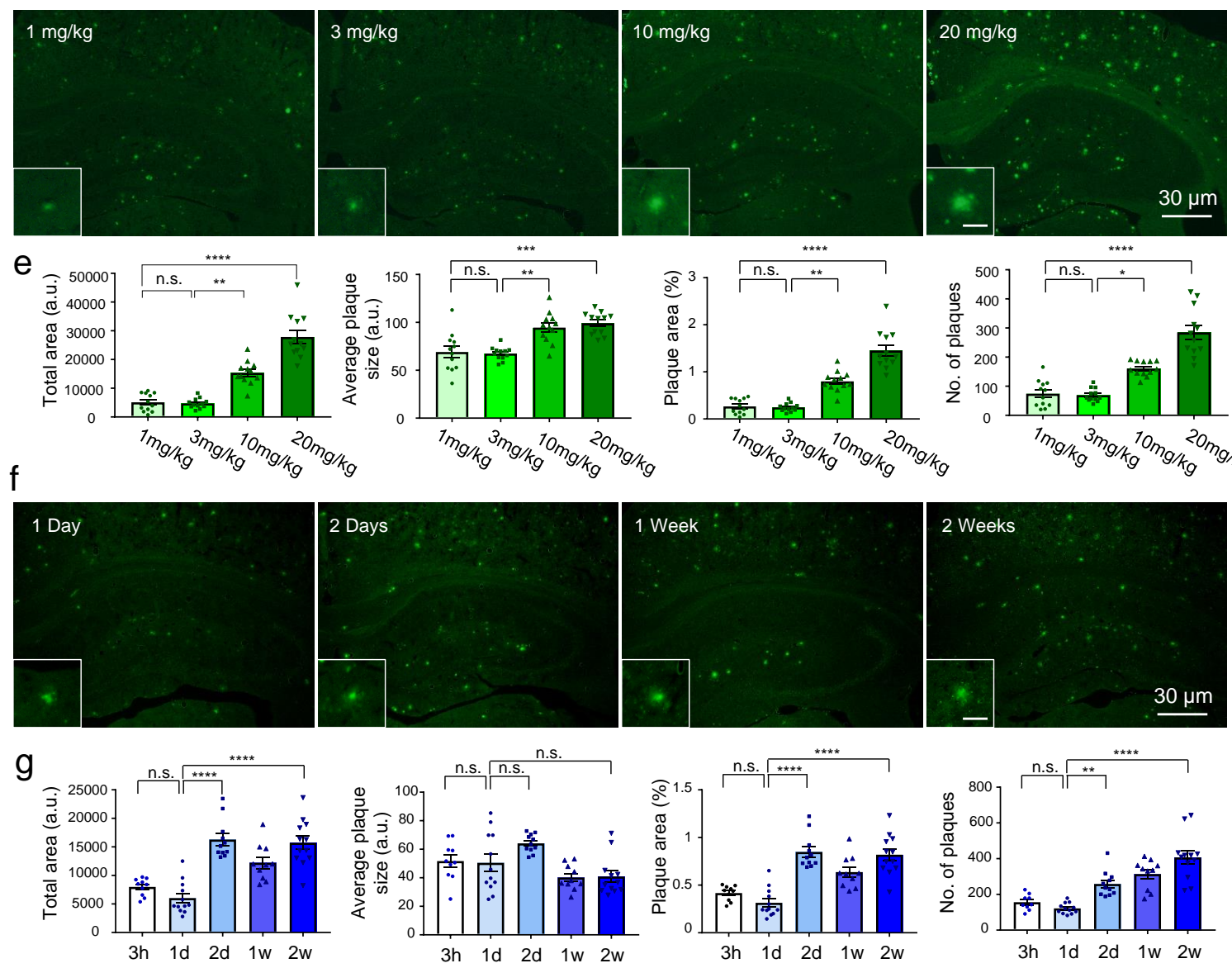

Figure S7. (a,b) Schematic diagram of the dose-dependent (a) and time-dependent (b) labeling experiments on tail-injected mice. (c) OPM images of an APP/PS1 mouse brain slice injected with DMSO (vehicle). (d,f) OPM images of APP/PS1 mouse brain slices 1 day after injection with $1-20 \mathrm{mg} / \mathrm{kg}$ PyrPeg (d) and $3 \mathrm{~h}$ to 2 weeks after injection with $1 \mathrm{mg} / \mathrm{kg}$ PyrPeg (f). Inset scale bar: $5 \mu \mathrm{m}$. (e,g) Total area, average plaque size, plaque area $(\%)$, and the number of plaques in the APP/PS1 mouse brain slices 1 day after injection with 1-20 mg/kg PyrPeg (d) and $3 \mathrm{~h}$ to 2 weeks after injection with $1 \mathrm{mg} / \mathrm{kg}$ PyrPeg (f). $* P<0.05$, ** $P<0.01$, *** $P<$ $0.001, * * * * P<0.0001$, one-way ANOVA with Tukey's multiple-comparison test. Representative images from replicate experiments $(n=3)$ are provided. 
(a)

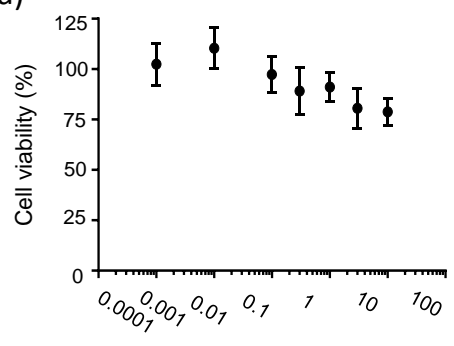

PyrPeg concentration $(\mu \mathrm{M})$ (b)

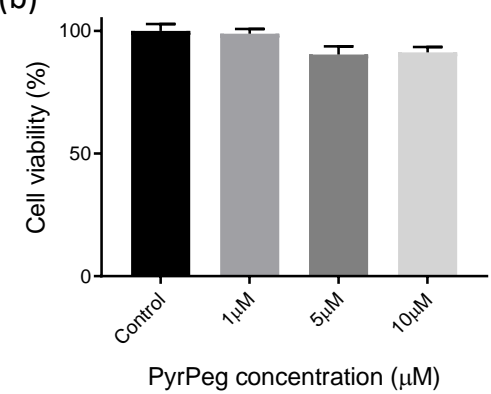

(c)

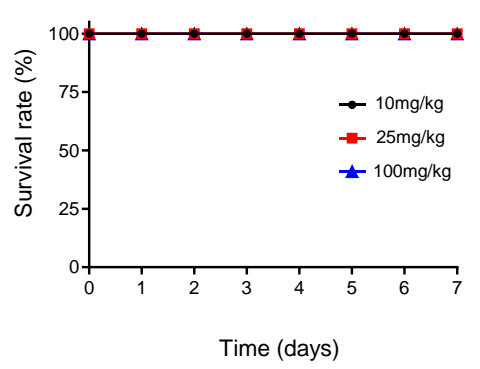

Figure S8. (a,b) Viability of PyrPeg-treated astrocytes according to the MTT assay (a) and viability of PyrPeg-treated SH-SY5Y cells according to the CCK-8 assay (b). The cells were incubated with PyrPeg $(1-10 \mu \mathrm{M})$ for $24 \mathrm{~h}$. (c) Survival rates of C57bl/6J mice 1-7 days after intravenous injection with PyrPeg (10-100 mg/kg) into the tail.

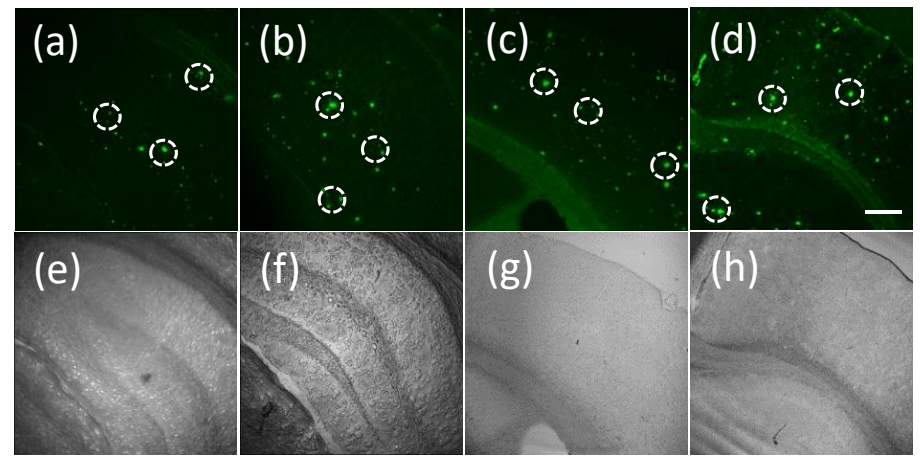

(g)

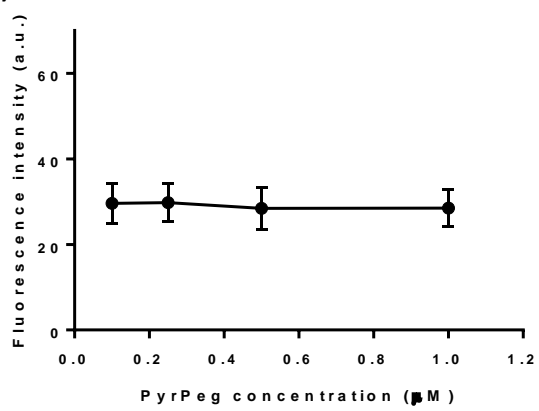

Figure S9. (a-d) TPM and (e-h) bright-field images of APP/PS1 mouse brain slices labeled with $0.1(\mathrm{a}, \mathrm{e}), 0.25(\mathrm{~b}, \mathrm{f}), 0.5(\mathrm{c}, \mathrm{g})$, or $1.0 \mu \mathrm{M}(\mathrm{d}, \mathrm{h})$ PyrPeg. TPM images were acquired at 450-650 nm upon excitation at $750 \mathrm{~nm}$. (g) The plot of TPEF intensity vs. PyrPeg concentration in the staining medium, as retrieved from the white circled regions in $(a-d)$. Scale bar: $100 \mu \mathrm{m}$. 

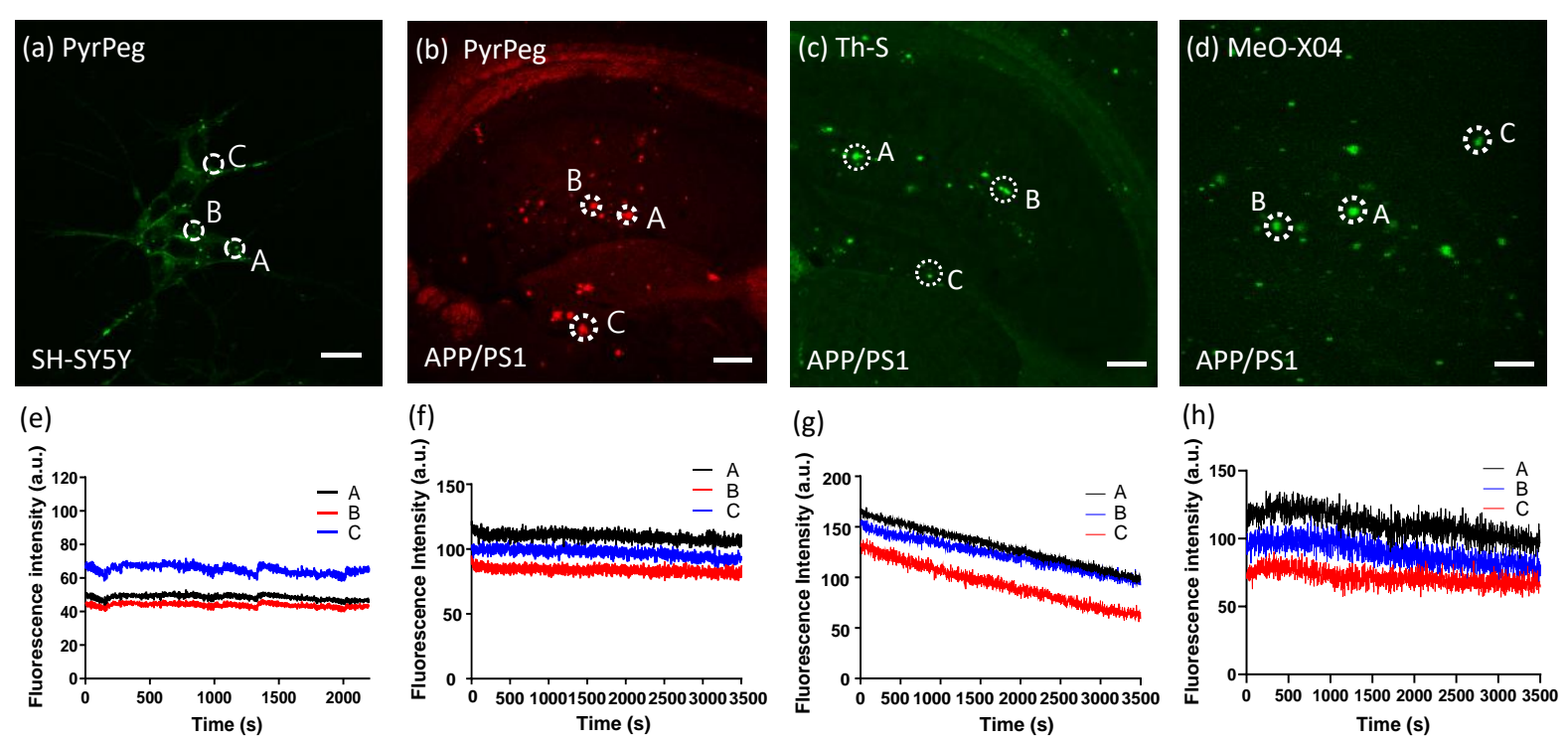

Figure S10. (a-d) TPM (a,b,d) and OPM (c) images of SH-SY5Y cells labeled with PyrPeg, and (b) APP/PS1 mouse brain slices labeled with PyrPeg (b) or Th-S (c). An APP/PS1 mouse brain slice 1 day after i.p. injection with MeO-X04 (2 mg/kg) (d). (e-h) Relative TPEF (a,b,d) and one-photon fluorescence intensities in regions $\mathrm{A}-\mathrm{C}$ as a function of time. The digitized intensity was recorded with $1.63 \mathrm{~s}$ intervals for $1 \mathrm{~h}$ in $x y t$ mode. The TPEF and one-photon fluorescence intensities were determined at 450-650 nm upon excitation at 750 and $458 \mathrm{~nm}$ with femtosecond pulses and continuous waves, respectively. Scale bar: $30 \mu \mathrm{m}$.
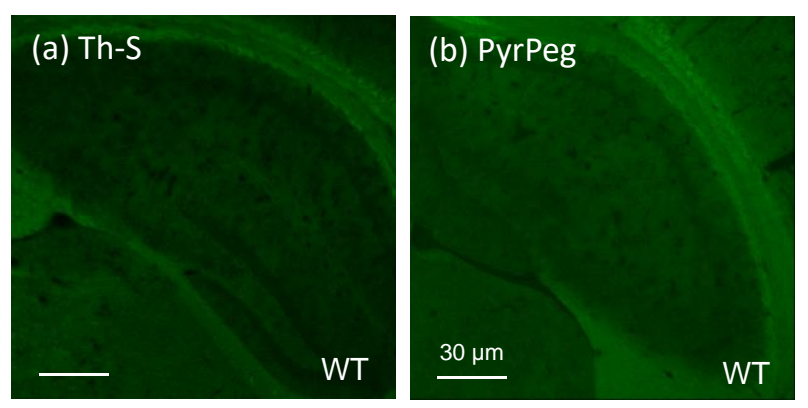

Figure S11. OPM images of WT mouse brain tissue labeled with Th-S (a) or PyrPeg (b). The fluorescence intensities were collected at 450-650 nm upon excitation at $458 \mathrm{~nm}$. Scale bar: $30 \mu \mathrm{m}$. 


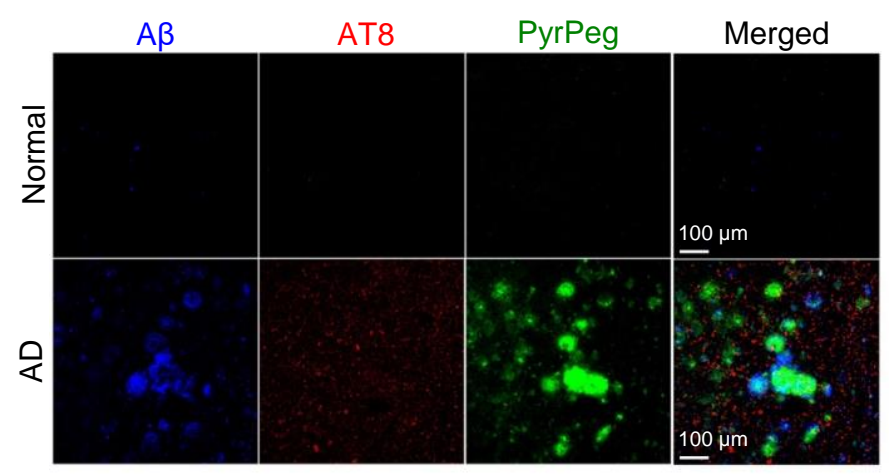

Figure S12. OPM images of the normal and AD patient's brain sections labeled with A $\beta$ (blue), AT8 (red), and PyrPeg (green) and a merged image.

(a)

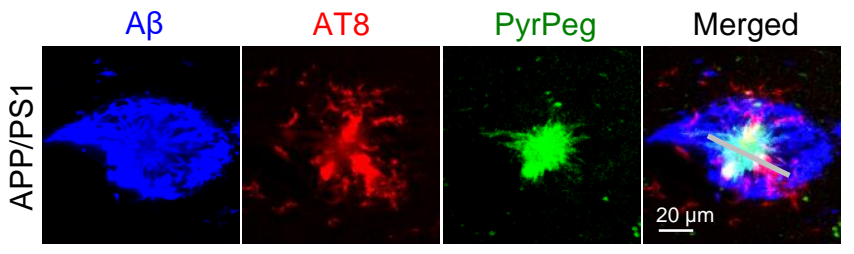

(b)

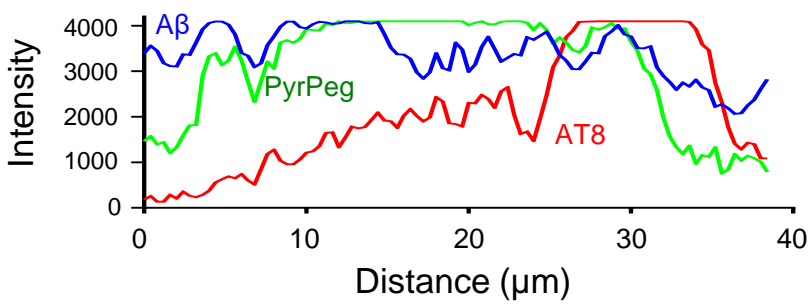

Figure S13. (a) OPM images of an APP/PS1 mouse brain section colabeled with A $\beta$ (blue), AT8 (red), and PyrPeg (green) and a merged image. (b) Line measurement analysis along the white line in the merged image of (a). Representative images from replicate experiments $(n=$ 3) are displayed. 
(a)

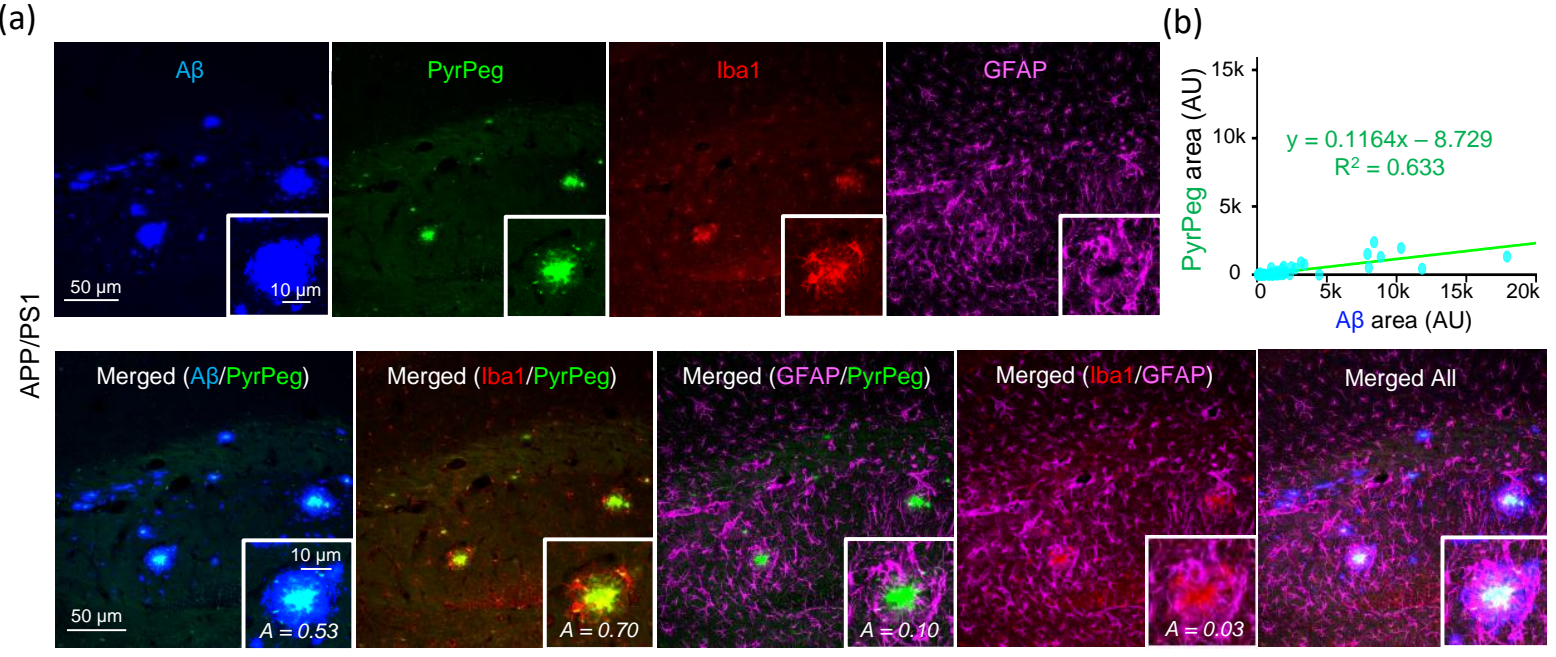

Figure S14. (a) OPM images of APP/PS1 mouse brain slices stained with an anti-A $\beta$ antibody (blue), PyrPeg (green), anti-Ibal antibody (red), and anti-GFAP antibody (magenta). Representative images from replicate experiments $(n=3)$ are shown. (b) A plot of PyrPegpositive vs. A $\beta$-positive areas using 103 data points from five OPM images. The green dots are the experimental data, and the straight line is the linear regression line that can be represented by the empirical equation shown in the figure.
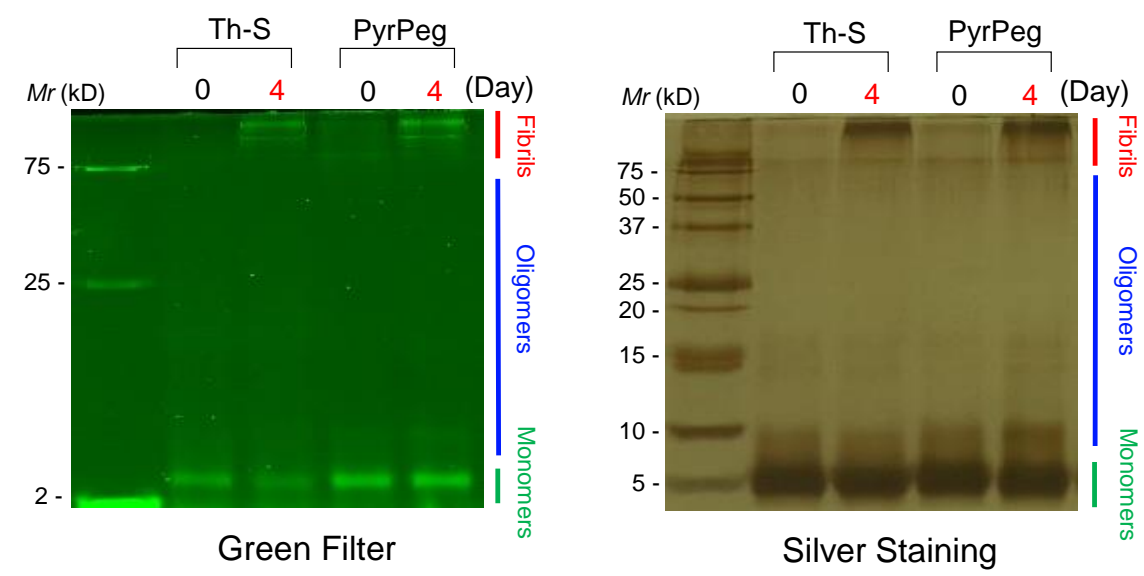

Figure S15. The gel analysis of the A $\beta 42$ mixture produced by incubating $A \beta 42$ monomer with Th-S or PyrPeg for 0 and 4 days, followed by photo-induced cross-linking of unmodified proteins. The image on the left was obtained by exciting the gel at $473 \mathrm{~nm}$ using a green filter, while that on the right was obtained by silver staining. The images show that $\mathrm{A} \beta 42$ fibrils are the predominant product after 4 days. 


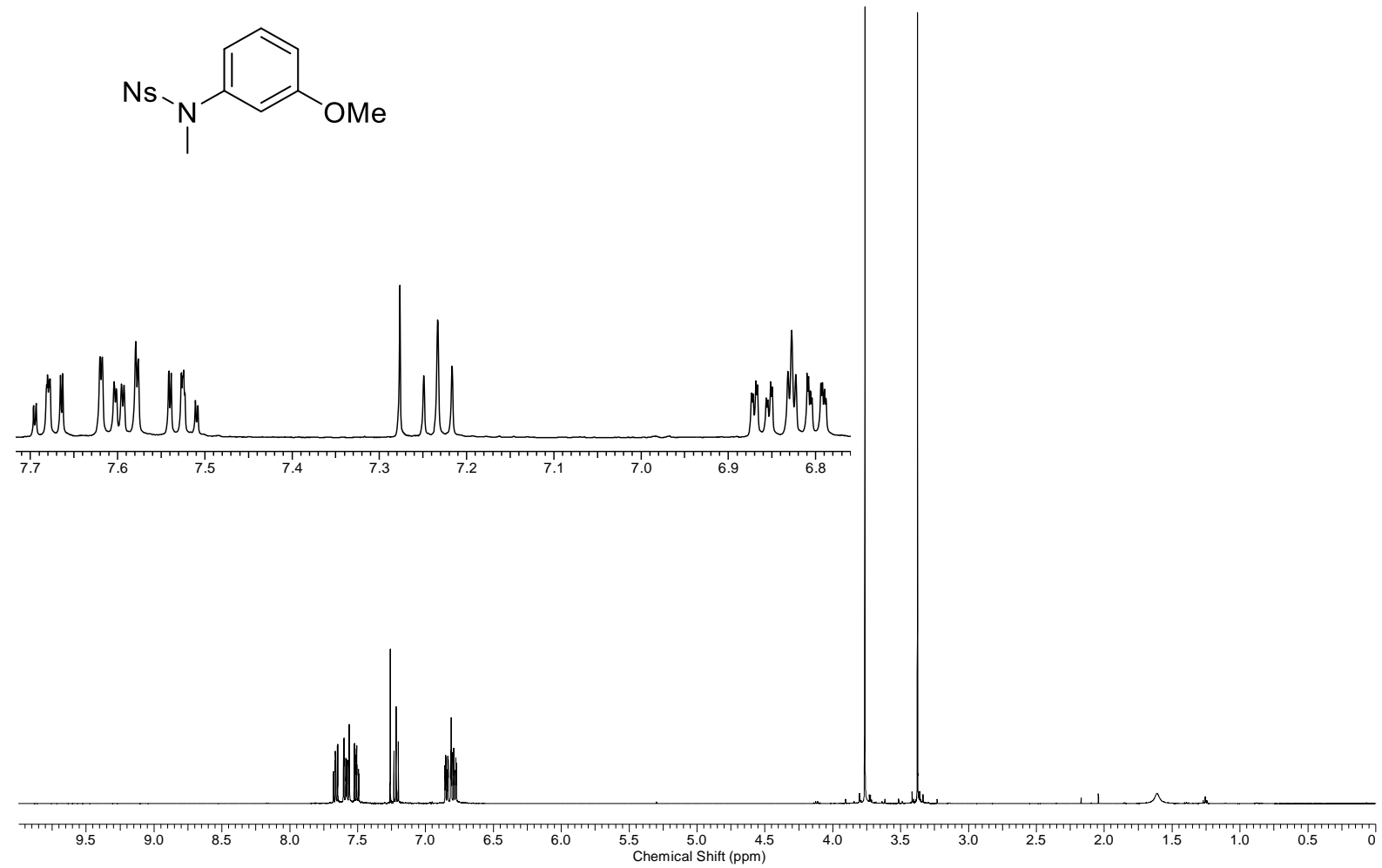

Figure S16. ${ }^{1} \mathrm{H}$ NMR $\left(500 \mathrm{MHz}, \mathrm{CDCl}_{3}\right)$ spectrum of compound 3.

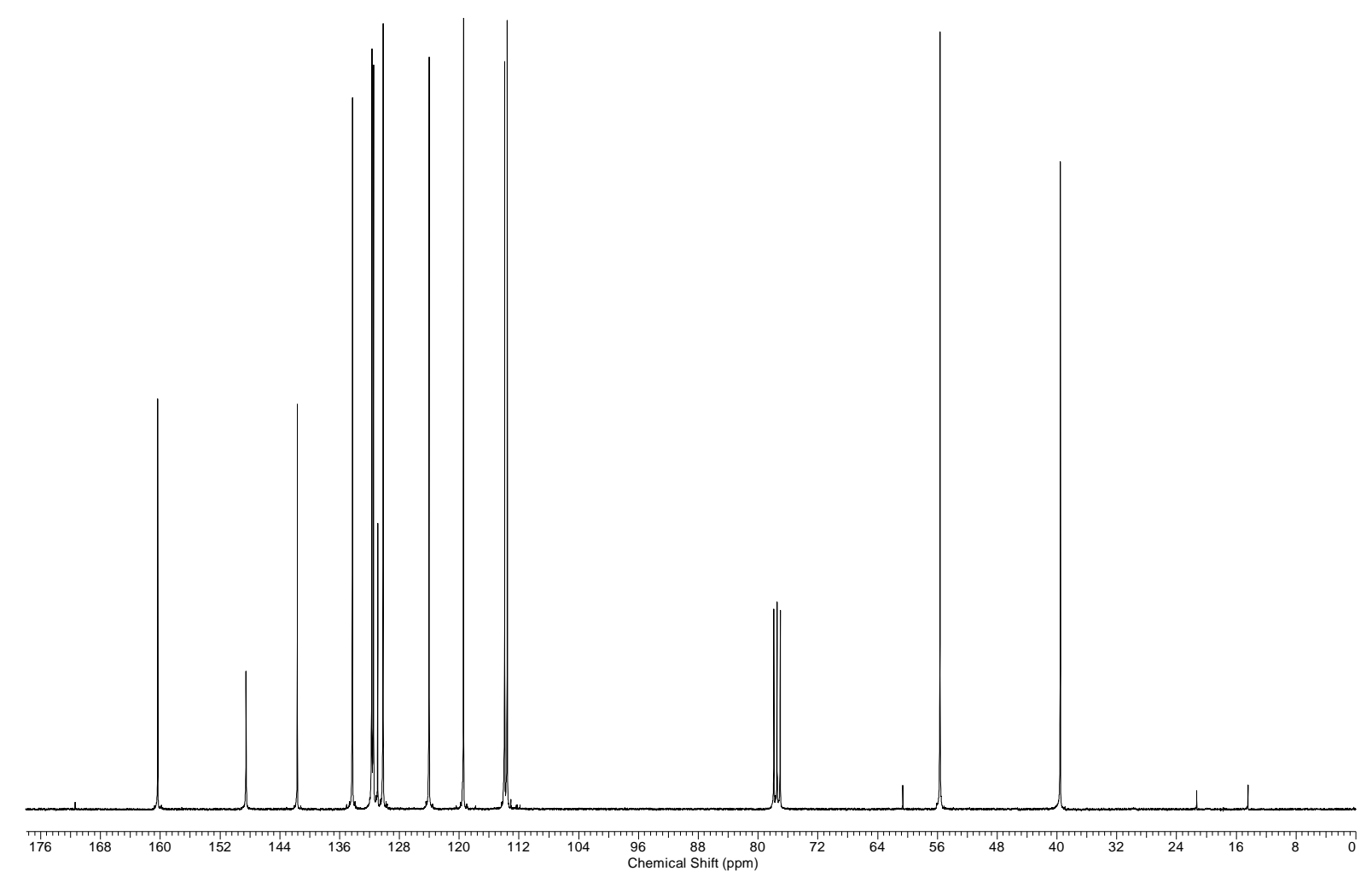

Figure S17. ${ }^{13} \mathrm{C}$ NMR (100 MHz, $\left.\mathrm{CDCl}_{3}\right)$ spectrum of compound 3. 


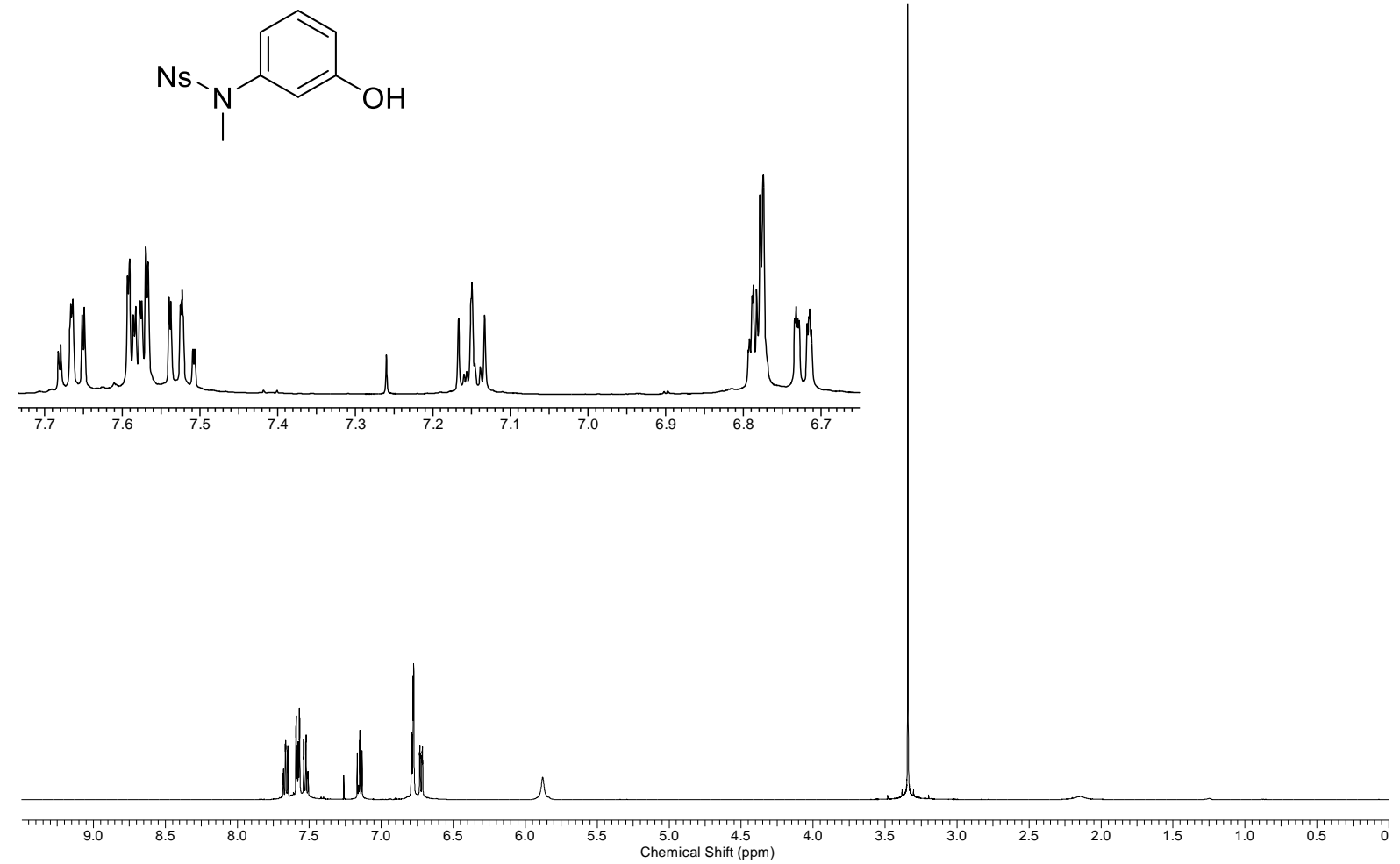

Figure S18. ${ }^{1} \mathrm{H} \mathrm{NMR}\left(500 \mathrm{MHz}, \mathrm{CDCl}_{3}\right)$ spectrum of compound 4.

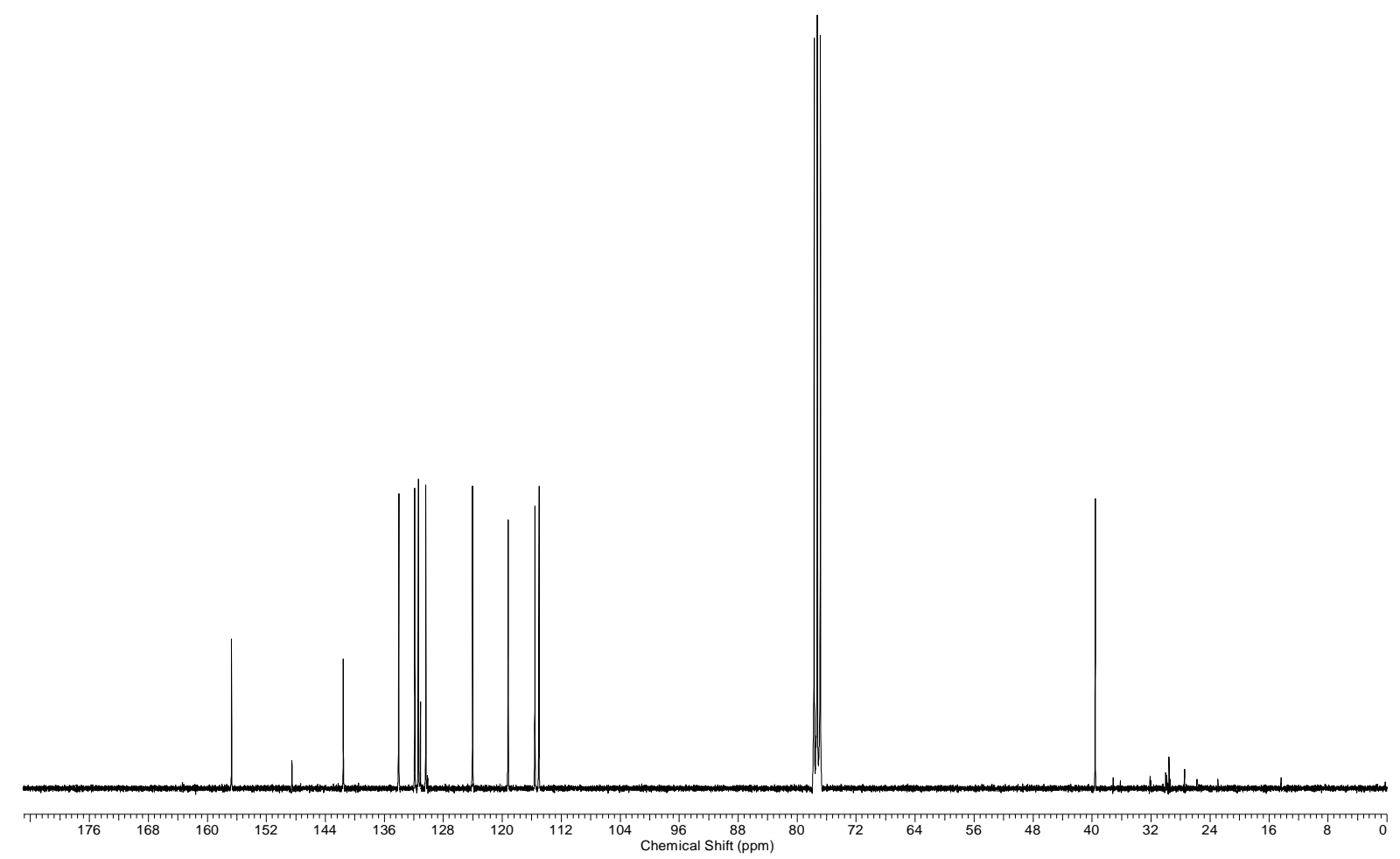

Figure S19. ${ }^{13} \mathrm{C}$ NMR $\left(100 \mathrm{MHz}, \mathrm{CDCl}_{3}\right)$ spectrum of compound 4. 

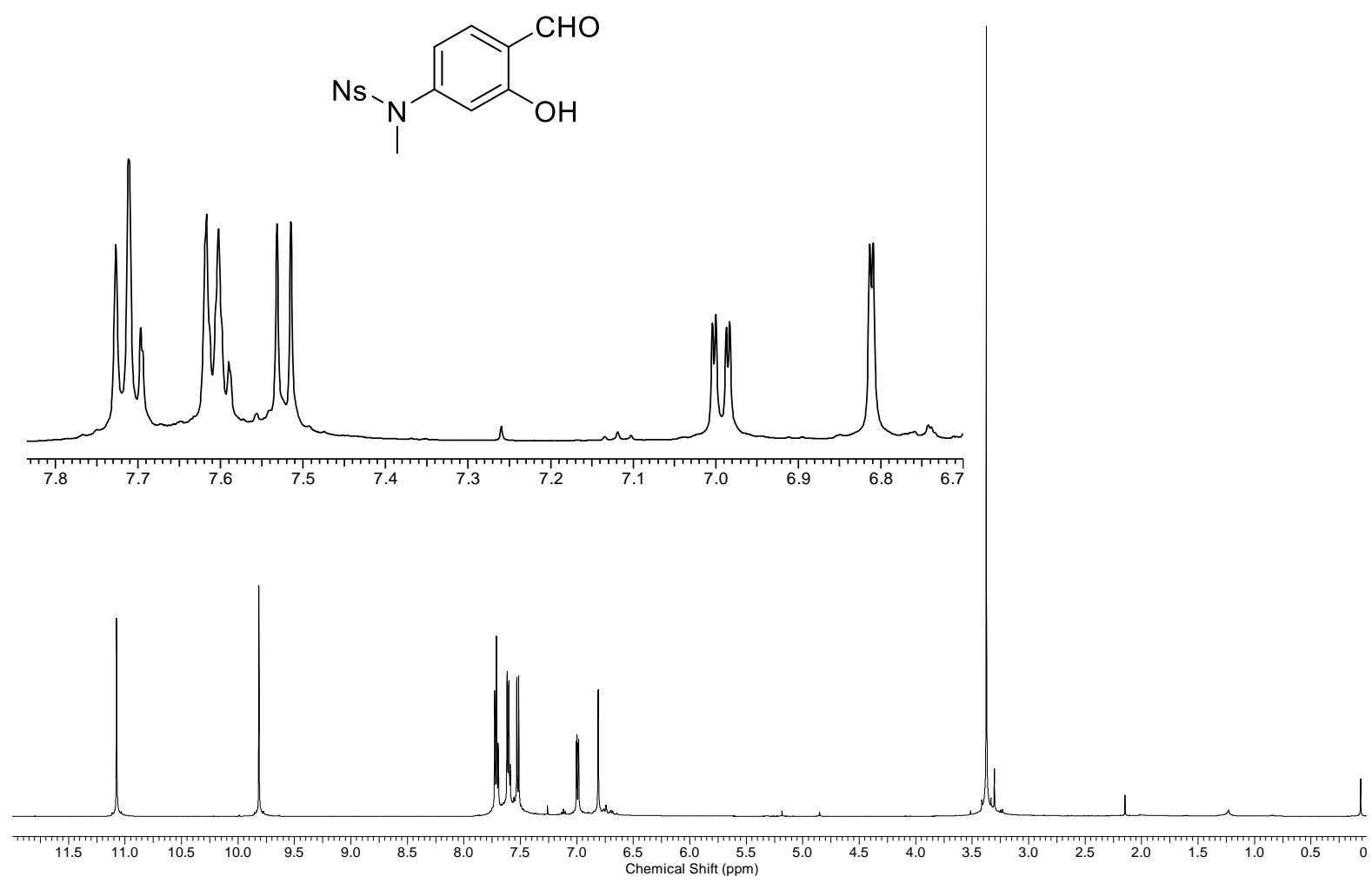

Figure S20. ${ }^{1} \mathrm{H}$ NMR $\left(500 \mathrm{MHz}, \mathrm{CDCl}_{3}\right)$ spectrum of compound 5.

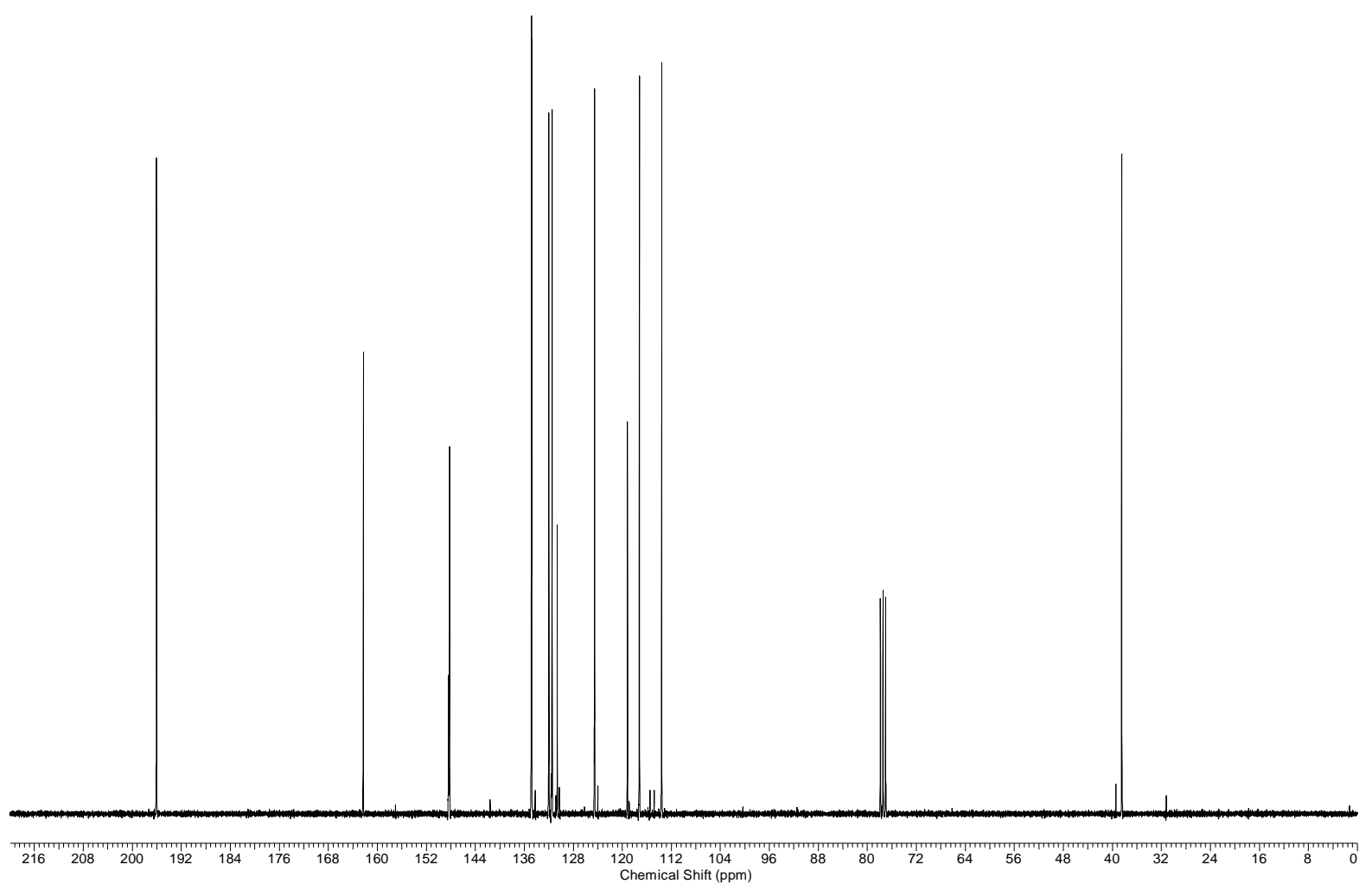

Figure S21. ${ }^{13} \mathrm{C}$ NMR $\left(100 \mathrm{MHz}, \mathrm{CDCl}_{3}\right)$ spectrum of compound 5. 
<smiles>COCCOCCOc1ccc2cc(-c3cnc(-c4cc5ccc(N(C)N)cc5o4)cn3)oc2c1</smiles>
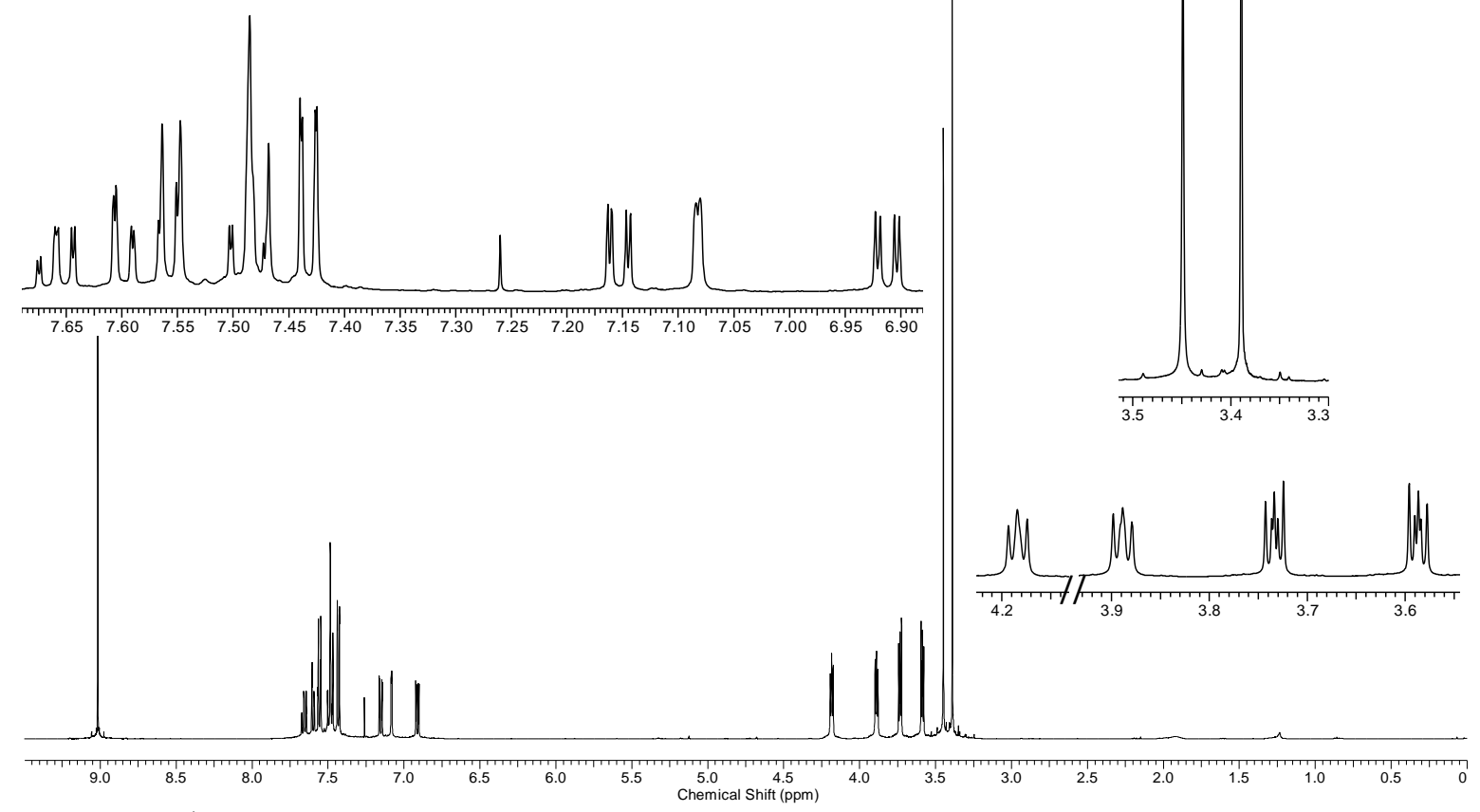

Figure S22. ${ }^{1} \mathrm{H}$ NMR $\left(500 \mathrm{MHz}, \mathrm{CDCl}_{3}\right)$ spectrum of compound 6.

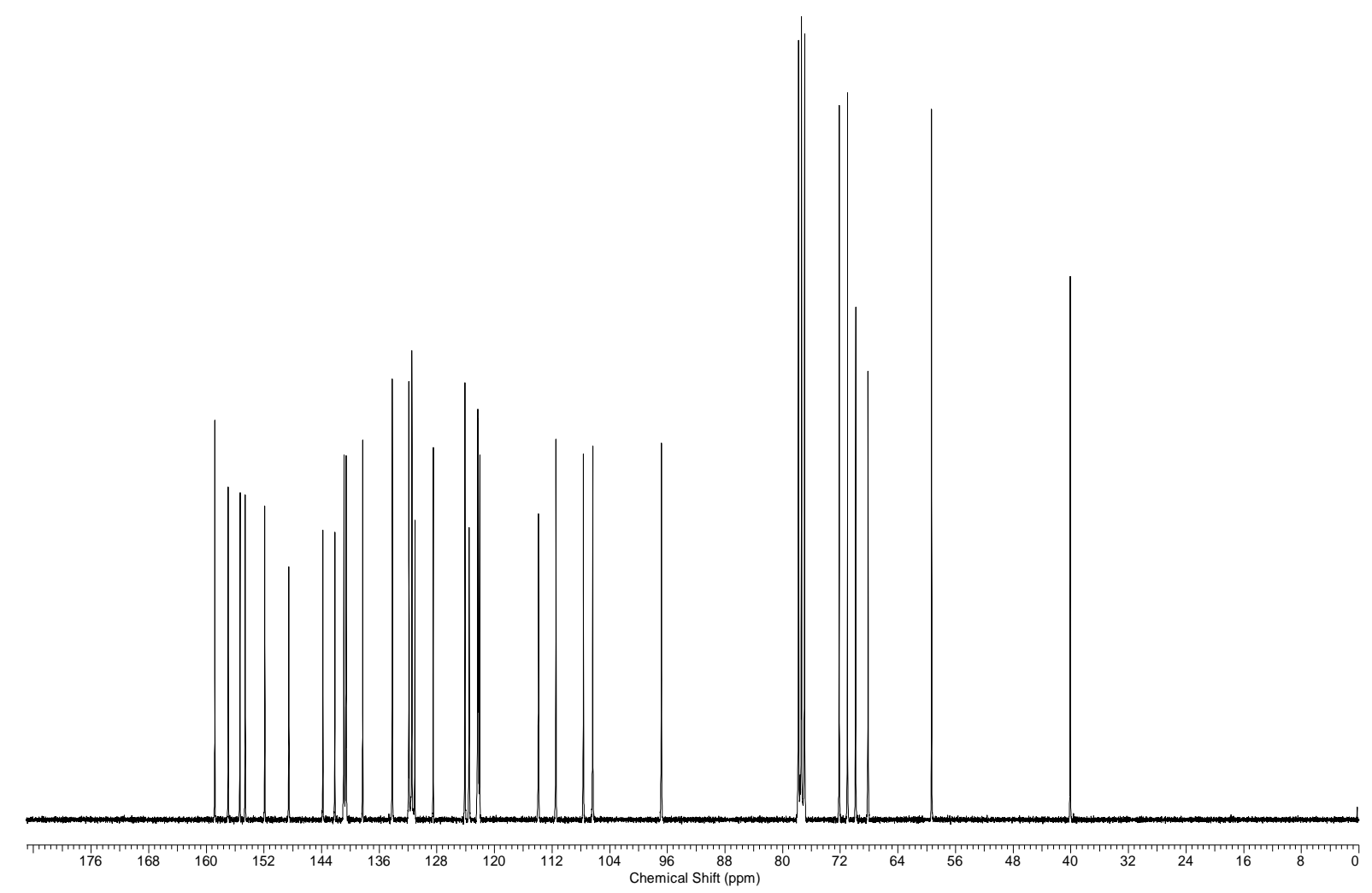

Figure S23. ${ }^{13} \mathrm{C}$ NMR $\left(100 \mathrm{MHz}, \mathrm{CDCl}_{3}\right)$ spectrum of compound 6 


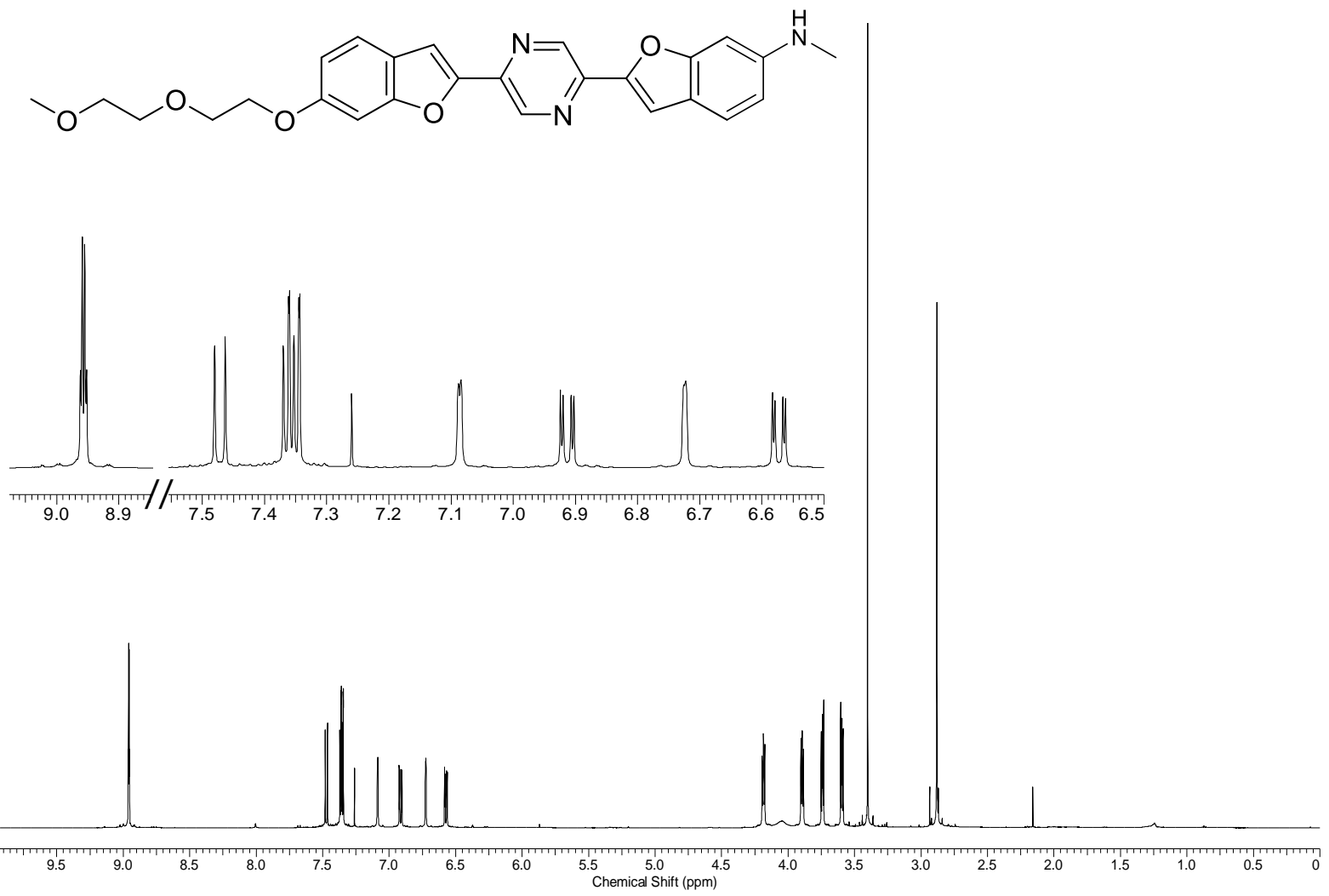

Figure S24. ${ }^{1} \mathrm{H}$ NMR (500 MHz, $\left.\mathrm{CDCl}_{3}\right)$ spectrum of PyrPeg

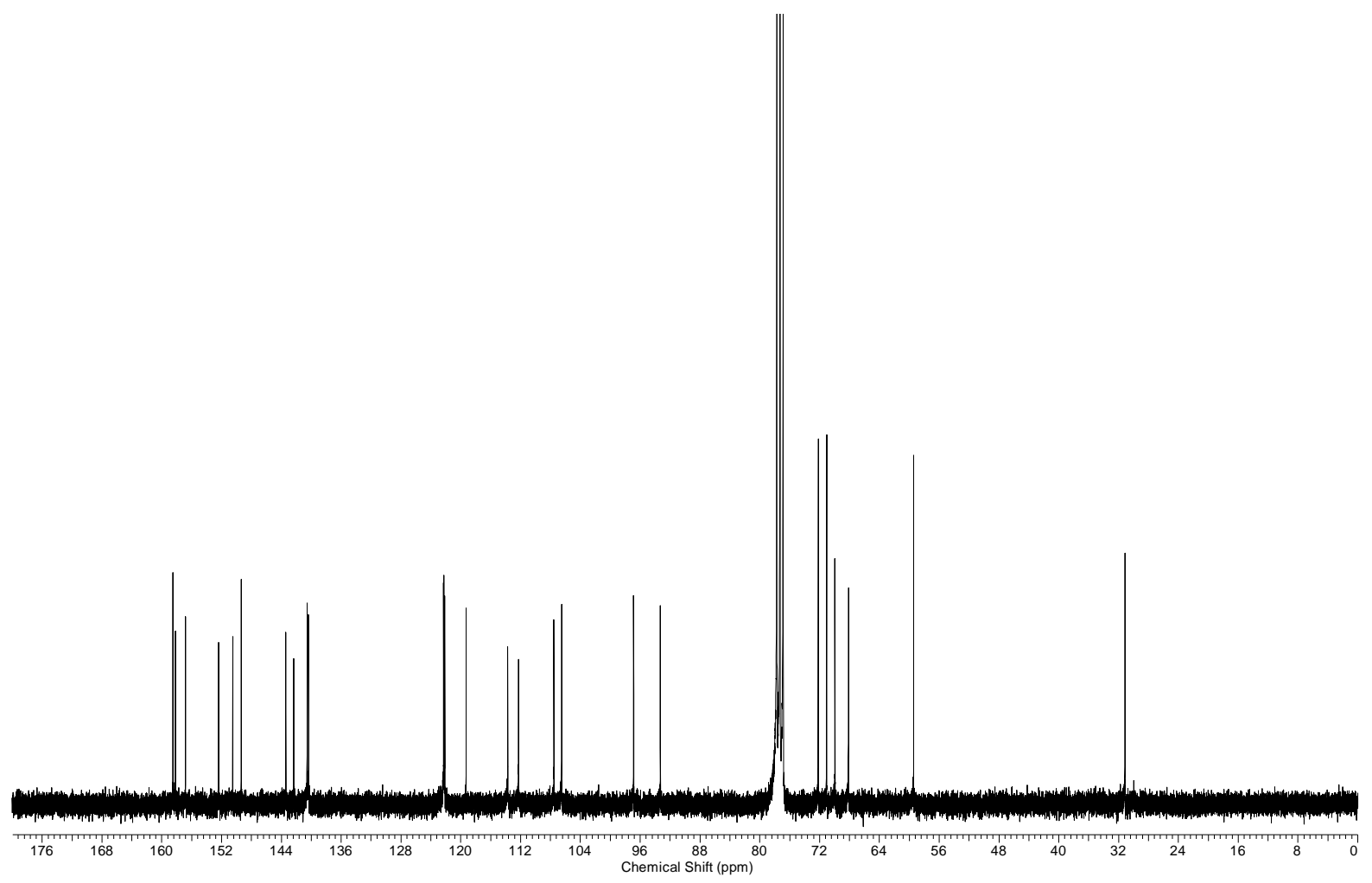

Figure S25. ${ }^{13} \mathrm{C}$ NMR $\left(100 \mathrm{MHz}, \mathrm{CDCl}_{3}\right)$ spectrum of PyrPeg 


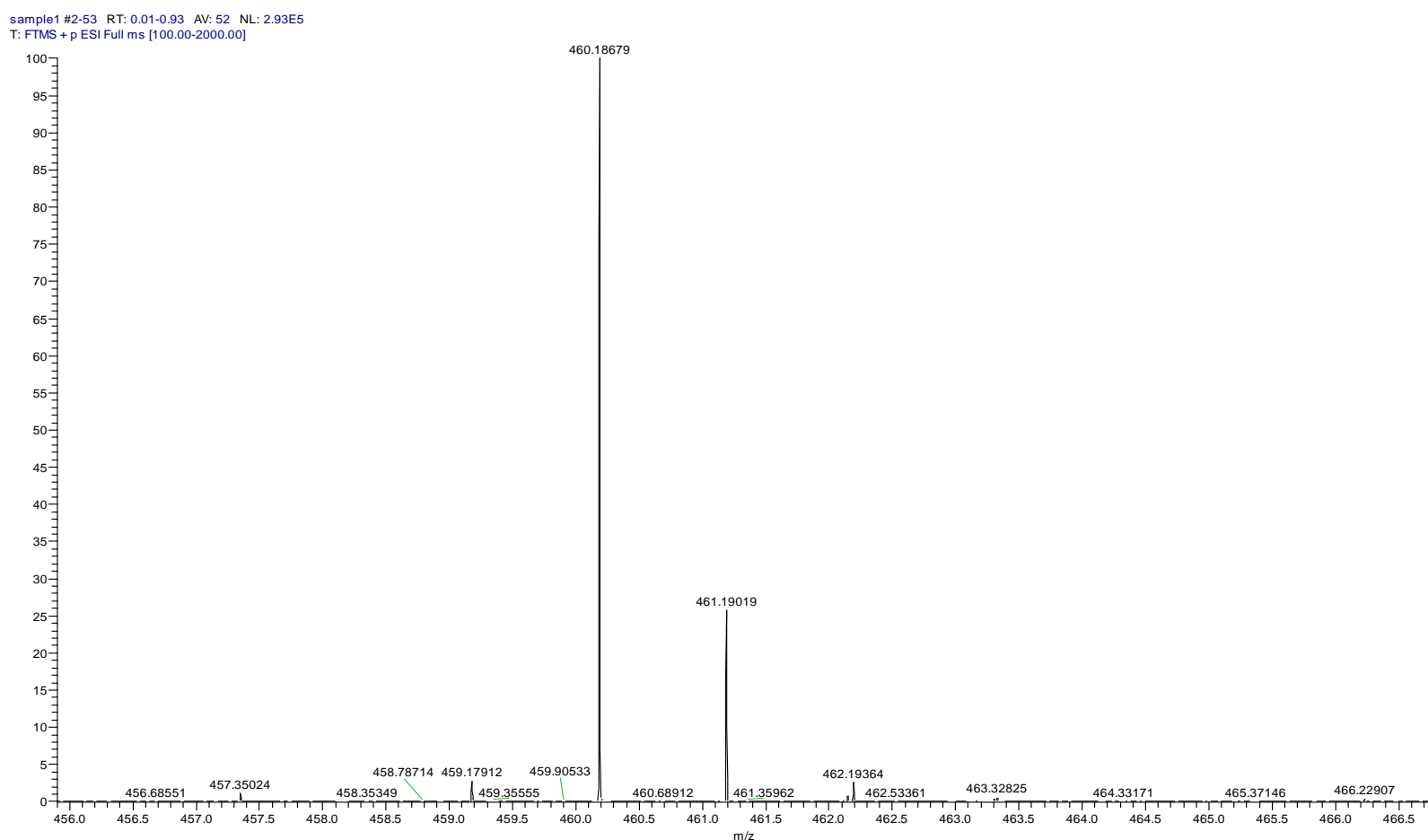

Figure S26. HRMS of PyrPeg. 
Table S1. Photophysical properties of PyrPeg, QAD1, SAD1, and A $\beta$ probe 5.

\begin{tabular}{|c|c|c|c|c|c|c|c|}
\hline Probe & $\begin{array}{c}\text { Solvent } \\
\left(E_{T}^{N}\right)^{[\mathrm{a}]}\end{array}$ & $K_{d}(\mathbf{n M})^{[\mathbf{b}]}$ & $\lambda_{\max }^{a b s} / \lambda_{\max }^{f l}$ & $\Delta \lambda_{f l}{ }^{[\mathrm{d}]}$ & $\Delta \overline{\boldsymbol{v}}^{[\mathrm{e}]}$ & $\boldsymbol{\Phi}^{[\mathrm{f}]}$ & $\delta_{\max }^{[\mathrm{g}]}$ \\
\hline \multirow{6}{*}{ PyrPeg $^{[\mathrm{h}]}$} & $\begin{array}{c}\text { Dioxane } \\
(0.164)\end{array}$ & & $441^{[\mathrm{i}]} / 525$ & - & - & 0.84 & 650 \\
\hline & $\begin{array}{c}\text { Dioxane } / \mathrm{H}_{2} \mathrm{O} \\
(33 / 1)\end{array}$ & & $440^{[\mathrm{i}]} / 560$ & - & - & 0.34 & 680 \\
\hline & $\begin{array}{c}\text { Dioxane } / \mathrm{H}_{2} \mathrm{O} \\
(20 / 1)\end{array}$ & & $440 / 582$ & - & - & 0.31 & - \\
\hline & $\begin{array}{c}\text { Dioxane } / \mathrm{H}_{2} \mathrm{O} \\
(10 / 1)\end{array}$ & & $444 / 598$ & - & - & 0.17 & - \\
\hline & $\begin{array}{c}\text { EtOH } \\
(0.654)\end{array}$ & & $447^{[\mathrm{i}]} / 629$ & 104 & $6.5 \times 10^{3}$ & 0.03 & - \\
\hline & Buffer (1.00) & 63.8 & $422^{[\mathrm{i}]} /-$ & - & - & 0.00 & - \\
\hline \multirow{3}{*}{ QAD1 $^{[j]}$} & $\begin{array}{c}\text { Dioxane } \\
(0.164)\end{array}$ & & $438 / 490$ & - & - & 1.00 & - \\
\hline & $\begin{array}{c}\text { EtOH } \\
(0.654)\end{array}$ & & $426 / 508$ & 18 & $3.8 \times 10^{3}$ & 0.73 & 575 \\
\hline & Buffer (1.00) & 16.2 & $407 / 546$ & - & - & 0.01 & - \\
\hline \multirow{3}{*}{ SAD1 ${ }^{[k]}$} & $\begin{array}{c}\text { Dioxane } \\
(0.164)\end{array}$ & & $363 / 429$ & - & - & 1.00 & - \\
\hline & $\begin{array}{c}\mathrm{EtOH} \\
(0.654)\end{array}$ & & $370 / 465$ & 36 & $5.5 \times 10^{3}$ & 1.00 & 170 \\
\hline & Buffer (1.00) & 17 & $362 / 497$ & - & - & 0.24 & - \\
\hline \multirow{3}{*}{$\mathbf{A} \beta \underset{5^{[l]}}{\text { probe }}$} & $\begin{array}{c}\text { Dioxane } \\
(0.164)\end{array}$ & & $500 / 613$ & - & - & - & - \\
\hline & $\begin{array}{c}\mathrm{EtOH} \\
(0.654)\end{array}$ & & $513 / 683$ & 70 & $4.9 \times 10^{3}$ & 1.00 & 4 \\
\hline & Buffer (1.00) & 44.6 & $540 /-$ & - & - & 0.00 & - \\
\hline Th-S & $\begin{array}{c}\mathrm{EtOH} \\
(0.654)\end{array}$ & & $372 / 497$ & 125 & $6.8 \times 10^{3}$ & 0.44 & 18 \\
\hline $\begin{array}{l}\text { MeO- } \\
\text { X04 }^{[\mathrm{m}]}\end{array}$ & $\begin{array}{c}\mathrm{EtOH} \\
(0.654)\end{array}$ & $26.8^{[\mathrm{n}]}$ & $373 / 456$ & 83 & $4.9 \times 10^{3}$ & 1.0 & 75 \\
\hline
\end{tabular}

${ }^{[\mathrm{a}]}$ The numbers in parentheses are normalized empirical parameters of solvent polarity. ${ }^{[\mathrm{b}]}$ Dissociation constants. The $K_{d}$ values of PyrPeg and SAD1 were measured by SPR spectroscopy, and those of QAD1 and $\mathrm{A} \beta$ probe 5 were determined by the fluorescence titration method. ${ }^{[\mathrm{c}]} \lambda_{\max }$ of the one-photon absorption and emission spectra in nanometers. ${ }^{[\mathrm{d}]}$ Solvatochromic shift for the change in the solvent from dioxane to EtOH. ${ }^{[\mathrm{e}]}$ The Stokes shift calculated from $\lambda_{\boldsymbol{m a x}}^{\boldsymbol{a b s}}$ and $\lambda_{\max }^{\boldsymbol{f l}}$ in EtOH. ${ }^{[\mathrm{fl}]}$ Fluorescence quantum yield. The uncertainty was set to $\pm 15 \%$. ${ }^{[\mathrm{g}]} \mathrm{TP}$ cross-section in GM, with an uncertainty of $\pm 15 \%$. ${ }^{[\mathrm{h}]}$ This work. ${ }^{[\mathrm{i}]}$ Molar absorption coefficients $(\varepsilon)$ measured in 1,4-dioxane, 1,4-dioxane- $-\mathrm{H}_{2} \mathrm{O}$ (33:1), EtOH, and PBS are 78,800, 70,850, 56,700, and 26,430, respectively. ${ }^{\left[{ }^{[j]}\right.}$ Ref. $2 .{ }^{[\mathrm{k}]}$ Ref. $3 .{ }^{\left[{ }^{[1]}\right.}$ Ref. 4. ${ }^{[\mathrm{m}]}$ Ref. 3. ${ }^{[\mathrm{n}]}$ Inhibition constant $\left(K_{\mathrm{i}}, \mathrm{nM}\right)$. 
Table S2. Human brain tissue samples of healthy subjects and AD patients. Braak stage and CERAD (Consortium to Establish a Registry for Alzheimer's Disease) score were presented.

\begin{tabular}{|c|c|c|c|c|}
\hline Case & Age & Sex & $\begin{array}{c}\text { Braak } \\
\text { stage }\end{array}$ & $\begin{array}{c}\text { CERAD } \\
\text { score }\end{array}$ \\
\hline Normal & 82 & Male & I & Not present (4) \\
\hline Normal & 88 & Male & I & Not present (4) \\
\hline Normal & 82 & Male & I & Not present (4) \\
\hline $\mathrm{AD}$ & 82 & Male & V & Definite (1) \\
\hline $\mathrm{AD}$ & 89 & Male & IV & Probable (2) \\
\hline $\mathrm{AD}$ & 83 & Male & VI & Definite (1) \\
\hline
\end{tabular}

Table S3. The PAMPA-BBB assay.

\begin{tabular}{|c|c|c|c|}
\hline Compound & $\left.\mathbf{P}_{\mathbf{e}} \mathbf{( 1 0}^{-\mathbf{6}} \mathbf{~ c m} / \mathbf{s}\right)$ & $-\log _{\mathbf{e}}$ & CNS prediction \\
\hline Theophylline & 3.443 & 5.463 & CNS \pm \\
\hline Lidocaine & 20.416 & 4.69 & CNS+ \\
\hline Progesterone & 20.465 & 4.689 & CNS+ \\
\hline Sample & 26.466 & 4.577 & CNS+ \\
\hline
\end{tabular}

Theophylline is a negative control (BBB non-penetrating, CNS-)

Lidocaine and progesterone are positive controls (BBB penetrating, $\mathrm{CNS}+$ )

\section{Reference.}

1. Choi, J. W.; Hong, S. T.; Kang, D. E.; Paik, K. C.; Han, M. S.; Lim, C. S.; Cho, B. R. Two-Photon Tracer for Human Epidermal Growth Factor Receptor-2. Anal. Chem. 2016, 88, 9412-9418.

2. Heo, C. H.; Sarkar, A. R.; Baik, S. H.; Jung, T. S.; Kim, J. J.; Kang, H.; Mook-Jung, I.; Kim, H. M. A quadrupolar two-photon fluorescent probe for in vivo imaging of amyloid-beta plaques. Chem. Sci. 2016, 7, 4600-4606.

3. Heo, C. H.; Kim, K. H.; Kim, H. J.; Baik, S. H.; Song, H.; Kim, Y. S.; Lee, J.; Mook-jung, I.; Kim, H. M. A two-photon fluorescent probe for amyloid-beta plaques in living mice. Chem. Commun. (Camb) 2013, 49, 1303-1305.

4. Kim, D.; Moon, H.; Baik, S. H.; Singha, S.; Jun, Y. W.; Wang, T.; Kim, K. H.; Park, B. S.; Jung, J.; Mook-Jung, I.; Ahn, K. H. Two-Photon Absorbing Dyes with Minimal Autofluorescence in Tissue Imaging. J. Am. Chem. Soc. 2015, 137, 6781-6789. 